\title{
Elemental composition of ambient aerosols measured with high temporal resolution using an online XRF spectrometer
}

\author{
Markus Furger $^{1}$, María Cruz Minguillón ${ }^{2}$, Varun Yadav ${ }^{3}$, Jay G. Slowik ${ }^{1}$, Christoph Hüglin ${ }^{4}$, Roman Fröhlich ${ }^{1}$, \\ Krag Petterson ${ }^{3}$, Urs Baltensperger ${ }^{1}$, and André S. H. Prévôt ${ }^{1}$ \\ ${ }^{1}$ Laboratory of Atmospheric Chemistry, Paul Scherrer Institute, 5232 Villigen PSI, Switzerland \\ ${ }^{2}$ Institute of Environmental Assessment and Water Research (IDAEA), Consejo Superior de Investigaciones Científicas \\ (CSIC), Jordi Girona 18-26, 08034 Barcelona, Spain \\ ${ }^{3}$ Cooper Environmental Services (CES), 9403 SW Nimbus Avenue, Beaverton, OR 97008, USA \\ ${ }^{4}$ Laboratory for Air Pollution/Environmental Technology, Empa, Überlandstrasse 129, 8600 Dübendorf, Switzerland \\ Correspondence to: Markus Furger (markus.furger@psi.ch)
}

Received: 23 November 2016 - Discussion started: 11 January 2017

Revised: 26 April 2017 - Accepted: 29 April 2017 - Published: 7 June 2017

\begin{abstract}
The Xact 625 Ambient Metals Monitor was tested during a 3-week field campaign at the rural, trafficinfluenced site Härkingen in Switzerland during the summer of 2015. The field campaign encompassed the Swiss National Day fireworks event, providing increased concentrations and unique chemical signatures compared to non-fireworks (or background) periods. The objective was to evaluate the data quality by intercomparison with other independent measurements and test its applicability for aerosol source quantification. The Xact was configured to measure 24 elements in $\mathrm{PM}_{10}$ with $1 \mathrm{~h}$ time resolution. Data quality was evaluated for $1024 \mathrm{~h}$ averages of Xact data by intercomparison with $24 \mathrm{~h} \mathrm{PM} 10$ filter data analysed with ICP-OES for major elements, ICP-MS for trace elements, and gold amalgamation atomic absorption spectrometry for $\mathrm{Hg}$. Ten elements ( $\mathrm{S}, \mathrm{K}$, $\mathrm{Ca}, \mathrm{Ti}, \mathrm{Mn}, \mathrm{Fe}, \mathrm{Cu}, \mathrm{Zn}, \mathrm{Ba}, \mathrm{Pb}$ ) showed excellent correlation between the compared methods, with $r^{2}$ values $\geq 0.95$. However, the slopes of the regressions between Xact 625 and ICP data varied from 0.97 to 1.8 (average 1.28) and thus indicated generally higher Xact elemental concentrations than ICP for these elements. Possible reasons for these differences are discussed, but further investigations are needed. For the remaining elements no conclusions could be drawn about their quantification for various reasons, mainly detection limit issues. An indirect intercomparison of hourly values was performed for the fireworks peak, which brought good agreement of total masses when the Xact data were corrected with the regressions from the $24 \mathrm{~h}$ value intercomparison. The re-
\end{abstract}

sults demonstrate that multi-metal characterization at hightime-resolution capability of Xact is a valuable and practical tool for ambient monitoring.

\section{Introduction}

The quantification of trace elements in airborne particulate matter (PM) can be achieved with various techniques, such as inductively coupled plasma mass spectrometry (ICP-MS), inductively coupled plasma optical emission spectrometry (ICP-OES), X-ray fluorescence spectrometry (XRF), and particle-induced X-ray emission spectrometry (PIXE). These methods require a two-step procedure, i.e. sample collection in the field followed by laboratory analysis. Ambient pollutants are conventionally collected on filter substrate for large time duration such as 8 or $24 \mathrm{~h}$ sampling time to ensure that sufficient elemental mass is available for analytical analysis (ICP). For high time resolution, impactors are used where the sample is collected on a foil (e.g. a rotating drum impactor; Lundgren, 1967) or on a combination of an impactor plate and a filter, such as in a streaker sampler (e.g. Annegarn et al., 1992). These samples are then exposed to Xrays or a particle beam without further treatment, which provide quantitative data with low detection limits. In contrast to the non-destructive XRF method, sample preparation for ICP analysis is very laborious, and the samples are destroyed during this process. The XRF method has been successfully 
applied to aerosol characterization in the last decades. Measurement of low sample mass typically requires high sensitivity (or a low minimum detection limit, MDL) and hence access to a synchrotron or accelerator facilities (Bukowiecki et al., 2005, 2008; Calzolai et al., 2010, 2015; Lucarelli et al., 2011; Richard et al., 2010; Visser et al., 2015b; Yatkin et al., 2016), which is notoriously difficult due to the demand for analysis time at such facilities. Access restrictions limit the number of collected samples to be analysed, and hence field campaigns are predominantly episodic. Technical advances in X-ray sources and detectors have recently resulted in the development of commercial systems capable of sampling and analysing ambient PM samples in sub-hourly or hourly resolution in quasi-real time. Instruments of this type can be used for continuous (months, years) monitoring at a site, but their cost may restrict the simultaneous deployment of a larger number of devices for different size fractions or at different sites. The benefit of long-term, quasi-real-time data access, favourable, for example, for air quality monitoring, contrasts with the possibilities of relatively low-cost, multi-site, and multi-size samplers used so far in episodic field studies.

Sampling with high time resolution generates large quantities of data capable of capturing source emission patterns occurring at shorter time duration. For source apportionment of PM components like elements, a high time resolution of the order of $1 \mathrm{~h}$ or less is advantageous, as temporally variable environmental factors such as wind direction and speed or insolation may affect transport and source processes, e.g. resuspension (Annegarn et al., 1992; D’Alessandro et al., 2003; Sánchez-Rodas et al., 2007; Sarmiento et al., 2007; Visser et al., 2015b; Yadav and Turner, 2014). One such instrument, Cooper Environmental's Xact ${ }^{\circledR} 625$ Ambient Metals Monitor, performs in situ automated measurements of ambient $\mathrm{PM}_{10}$ or $\mathrm{PM}_{2.5}$ elemental concentrations for a user-defined set of 24 or more elements with a user-selected sampling time resolution of 15 to $240 \mathrm{~min}$. The instrument is transportable and can be deployed in field campaigns where a suitable shelter with electric power and an appropriate sampling line connecting the outdoor with the indoor is available. Remote access to the data is possible during operation, which allows for a continuous, quasi-real-time (i.e. with a delay of one sampling interval) monitoring of the operation status and the ambient metal content. An in-depth evaluation of the forerunner instrument Xact 620 was previously published by Park et al. (2014).

An Xact 625 monitor was deployed for a month to test the handling and data production of the instrument. A small field campaign was organized at a monitoring station of the Swiss Air Pollution Monitoring Network (NABEL), where qualitycontrolled air pollution measurements are performed continuously. The NABEL network provided the reference for previous data intercomparisons (Hueglin et al., 2005; Lanz et al., 2010), as well as for the intercomparisons of this study. Comparisons between SR-XRF and filter samples analysed with ICP-OES and ICP-MS have been performed previously (Richard et al., 2010). Comparisons of XRF on samples collected on different substrates were performed, e.g. by Yatkin et al. (2012). A recent interlaboratory comparison of $\mathrm{PM}_{10}$ filter analysis methods is presented in Yatkin et al. (2016), where XRF/PIXE and ICP methods were compared for several metrics. Some of these metrics are also applied in this study.

The goals of this article are (1) to characterize the measurements of the test period in Härkingen and compare them with previous studies in Switzerland; (2) to examine the achieved data quality for the selected elements with respect to their MDLs; (3) to quantify the measurement quality based on intercomparisons between the Xact and NABEL PM 10 data ( $1 \mathrm{~h}$ tapered element oscillating microbalance (TEOM) data and $24 \mathrm{~h}$ filter samples) for Härkingen; (4) to evaluate the applicability of the instrument at high time resolution in typical summer conditions and concentration ranges at a traffic-influenced rural site in Switzerland; and (5) to gauge the advantages of high-time-resolution sampling for a preliminary investigation of sources based on enhancement ratios and diurnal variability of elements. A pollution episode captured during the campaign resulted in high ambient concentrations, widening the range of studied concentrations. The selected elements represented a typical mix of elements at the selected site. In addition, a few elements notoriously difficult to measure in Switzerland due to their generally low ambient concentration were included, namely $\mathrm{Ni}, \mathrm{As}, \mathrm{Pt}$, and Hg.

\section{Experimental set-up}

\subsection{Site characteristics}

The field campaign was performed at the permanent station Härkingen $\left(47.311877^{\circ} \mathrm{N}, 7.820453^{\circ} \mathrm{E}\right)$ of NABEL (http:// www.bafu.admin.ch/luft/00612/00625/index.html?lang=en) from 23 July until 13 August 2015. This station is located next to the A1 freeway, the main traffic route between eastern and western Switzerland. About $1 \mathrm{~km}$ to the west the A2 freeway branches off towards the north. The local terrain is level and the traffic flows freely even during rush hours, limiting incidences of excessive braking or forced acceleration. There are villages to the south and east of the site, and agricultural land immediately to the west and north. Other local activities include industrial buildings approximately $500 \mathrm{~m}$ to the north-west (logistics businesses) and a metal processing company to the south-east across the freeway. The site is well documented with respect to gas-phase traffic emissions, PM number concentrations, and particulate elemental carbon (EC; Hueglin et al., 2006), but an in-depth local source apportionment has not been realized so far except for organic aerosols measured in May 2005 (Lanz et al., 2010). 
The first week of the campaign was characterized by moderate summer temperatures (maximum temperature $<25^{\circ} \mathrm{C}$, except 23 July) with some occasional rain cleansing the atmosphere. The remaining 2 weeks were part of a summer heat wave, with temperatures reaching $36.4^{\circ} \mathrm{C}$ at the maximum and values above $30^{\circ} \mathrm{C}$ on 7 days of this period. Only one precipitation event occurred during the hot period. The Swiss National Day (1 August) fell on a Saturday, and the weekend weather promoted outdoor barbecues and fireworks. The bulk of the fireworks were burnt on 1 August after 22:00 LT (local time $=\mathrm{UTC}+2 \mathrm{~h}$ ), but some individual fireworks were also burnt on 31 July and 2 and 3 August.

For this study, the Xact 625 monitor and a Q-ACSM (quadrupole aerosol chemical speciation monitor, Aerodyne Inc.) were installed in an air-conditioned trailer parked next to the NABEL station. This trailer was placed to the north of the freeway at $\sim 23 \mathrm{~m}$ away from the centre of the freeway. This placed the trailer on the orthogonal transect between the freeway and NABEL shelter, which is located $\sim 27 \mathrm{~m}$ from the centre of the freeway. The trailer's instruments were connected to the NABEL station's power grid and Ethernet.

\subsection{NABEL instrumentation}

The NABEL station is equipped with a broad range of air quality instrumentation and standard meteorological sensors. The relevant instruments for this field test were the Digitel DA-80H HiVol sampler with a DPM 10/30/00 inlet for $24 \mathrm{~h}$ $\mathrm{PM}_{10}$ sample collection and a TEOM Filter Dynamics Measurement System (FDMS 8500, Thermo Scientific) for continuous (10 min) $\mathrm{PM}_{10}$ mass concentration measurements. The time constant used for noise reduction in the TEOM and the averaging procedure caused a significant time delay in peak concentrations. For $1 \mathrm{~h}$ values, the random error of a TEOM as derived from parallel operation of two identical instruments is about $2 \mu \mathrm{g} \mathrm{m}^{-3}$. Standard meteorological measurements such as temperature, wind speed, and direction, and precipitation records are also monitored at this station. Furthermore, the station also provided hourly traffic counts for the freeway in the form of total number of vehicles, number of heavy-duty vehicles (HDV), and number of light-duty vehicles (LDV).

\subsection{Xact 625}

The Xact 625 Ambient Metals Monitor (Cooper Environmental Services (CES), Beaverton, OR, USA) is a sampling and analysing X-ray fluorescence spectrometer designed for online, semi-continuous measurements of elements in aerosols. In this study, ambient air was sampled with a flow rate of 16.7 actual lpm through a $\mathrm{PM}_{10}$ flow separator (Tisch Environmental, TE-PM10-D) and the PM collected onto a Teflon filter tape. The flow is maintained to within about $1 \%$. After each sampling interval the filter tape is moved into the analysis area of the spectrometer, where it is illuminated with an X-ray tube with three excitation conditions, and the excited X-ray fluorescence is measured with a silicon drift detector (SDD). During this XRF analysis, the next sample is collected on a clean spot of the filter tape. This cycle is repeated during each sampling interval, which was configured to be $60 \mathrm{~min}$ for this study. While this approach is non-destructive, the samples collected are typically not amenable to offline analysis post-sampling due to potential for cross-contamination from sampled filter tape wound upon itself onto the filter wheel. After each analysis interval, raw and calibrated (for the actual volume in units of $\mathrm{ng} \mathrm{m}^{-3}$ ) concentration data were stored on the hard disk of the control unit. Daily advanced quality assurance checks (QA energy calibration test, QA upscale test) were performed during $30 \mathrm{~min}$ after midnight to monitor shifts in the calibration. Thus, the sampling interval following midnight was limited to 30 min only.

The instrument was configured to quantify 24 elements ( $\mathrm{Si}, \mathrm{S}, \mathrm{Cl}, \mathrm{K}, \mathrm{Ca}, \mathrm{Ti}, \mathrm{V}, \mathrm{Cr}, \mathrm{Mn}, \mathrm{Fe}, \mathrm{Co}, \mathrm{Ni}, \mathrm{Cu}, \mathrm{Zn}, \mathrm{As}$, $\mathrm{Se}, \mathrm{Cd}, \mathrm{Sn}, \mathrm{Sb}, \mathrm{Ba}, \mathrm{Pt}, \mathrm{Hg}, \mathrm{Pb}, \mathrm{Bi}$, plus Pd for QA). Each of these elements was calibrated individually with a reference sample. MDLs for $1 \mathrm{~h}$ sampling for each element are listed in Table 1. CES calculates MDLs using the sensitivity of the element and the counts in the region of interest of a blank unsampled section of tape, from where $1 \sigma$ interference-free detection limits are reported. XRF-based MDLs are inversely proportional to the square root of the X-ray analysis time (Currie, 1977), which in the case of Xact is the same as the sampling duration. Hence, Xact MDLs are lower for longer sampling durations. Interference-free MDLs, while true are idealized lower limits of detection of one single element. As with most analytical methods, matrix effects in ambient samples from interferences between different elements and analyte concentrations could potentially result in MDLs of ambient samples to be higher and vary across samples, which makes them difficult to generalize and report. It is therefore often preferred to report measurement uncertainties to characterize a measurement. An uncertainty of $5 \%$ or less due to fitting errors and uncertainties in the standards has been derived from laboratory experiments with NIST standards (benchtop XRF, filter analyses). Uncertainties are expected to be higher for concentrations close to the MDL, for elements with potential for line interferences in multi-element samples, and, from self absorption effects, for the lightest elements ( $\mathrm{Si}, \mathrm{S}, \mathrm{Cl}, \mathrm{K}, \mathrm{Ca}$ ). Line interference is well-known for element couples like $\mathrm{Fe}-\mathrm{Co}, \mathrm{Pb}-\mathrm{As}$, and $\mathrm{Ba}-\mathrm{Ti}$ and makes detection of one element difficult if the other is abundant in the sample. The linear least-squares reference deconvolution algorithm implemented in the Xact fits the measured sample spectrum with the library of pure element reference spectra to resolve concentrations of each calibrated element. The Xact reports purely elemental mass concentrations, which are the focus of discussion and unless otherwise noted. 
Table 1. Regression coefficients for the comparison of Xact 625 and offline data. The $1 \mathrm{~h}$ values of the Xact 625 were averaged to $24 \mathrm{~h}$ values. Primed quantities are uncertainties.

\begin{tabular}{|c|c|c|c|c|c|c|c|c|c|c|c|c|c|}
\hline \multirow{3}{*}{ Group } & \multirow{3}{*}{ Element } & \multirow{3}{*}{$\begin{array}{l}\text { Analysis } \\
\text { method }\end{array}$} & \multicolumn{7}{|c|}{ Regression coefficients } & \multicolumn{2}{|c|}{ Xact } & \multicolumn{2}{|c|}{ ICP $(24 h)$} \\
\hline & & & \multicolumn{5}{|c|}{ fitX $=a+b x$} & \multirow{2}{*}{$\begin{array}{r}\text { Average } \\
\text { XRF conc. } \\
\mathrm{ng} \mathrm{m}^{-3}\end{array}$} & \multirow[t]{2}{*}{$\begin{array}{r}\text { Ratio intercept/ } \\
\text { average }\end{array}$} & \multirow{2}{*}{$\begin{array}{r}\text { MDL } \\
(60 \mathrm{~min}) \\
\mathrm{ng} \mathrm{m}^{-3}\end{array}$} & \multirow{2}{*}{$\begin{array}{r}\text { Pts }>\text { MDL } \\
\%\end{array}$} & \multirow{2}{*}{$\begin{array}{r}\text { MDL } \\
(24 \mathrm{~h}) \\
\mathrm{ng} \mathrm{m}^{-3}\end{array}$} & \multirow{2}{*}{$\begin{array}{r}\text { Pts }>\text { MDL } \\
\%\end{array}$} \\
\hline & & & $a$ & $\pm a^{\prime}$ & $b$ & $\pm b^{\prime}$ & $r^{2}$ & & & & & & \\
\hline \multirow[t]{10}{*}{ A } & $S$ & ICP-OES & -170 & 30.6 & 1.37 & 0.03 & 1.00 & 956 & -0.18 & & & 7.7 & 100 \\
\hline & $\mathrm{K}$ & ICP-OES & 52.4 & 19.2 & 1.15 & 0.02 & 1.00 & 703 & 0.07 & 4.20 & 100 & 37.8 & 100 \\
\hline & $\mathrm{Ca}$ & ICP-OES & 13.9 & 17.9 & 1.45 & 0.06 & 0.99 & 365 & 0.04 & 1.60 & 100 & 49.2 & 90 \\
\hline & $\mathrm{Ti}$ & ICP-MS & 5.58 & 0.57 & 1.13 & 0.06 & 0.98 & 14.9 & 0.37 & 0.68 & 100 & 1.04 & 90 \\
\hline & $\mathrm{Mn}$ & ICP-MS & 1.72 & 0.28 & 1.31 & 0.06 & 0.99 & 7.6 & 0.23 & 0.51 & 100 & 0.26 & 100 \\
\hline & $\mathrm{Fe}$ & ICP-OES & 93.1 & 35.8 & 1.34 & 0.08 & 0.97 & 656 & 0.14 & 1.40 & 100 & 3.4 & 100 \\
\hline & $\mathrm{Cu}$ & ICP-MS & 4.93 & 1.27 & 1.27 & 0.05 & 0.99 & 33.5 & 0.15 & 0.48 & 100 & 0.055 & 100 \\
\hline & $\mathrm{Zn}$ & ICP-MS & -5.56 & 2.18 & 1.80 & 0.13 & 0.96 & 23.0 & -0.24 & 0.41 & 100 & 0.96 & 100 \\
\hline & $\mathrm{Ba}$ & ICP-MS & -1.62 & 1.73 & 1.01 & 0.03 & 0.99 & 31.9 & -0.05 & 1.70 & 94 & 0.82 & 100 \\
\hline & $\mathrm{Pb}$ & ICP-MS & 0.32 & 0.17 & 0.97 & 0.04 & 0.99 & 3.8 & 0.08 & 0.39 & 98 & 0.22 & 100 \\
\hline average & & & & & 1.28 & & & & & & & & \\
\hline standard deviation & & & & & 0.24 & & & & & & & & \\
\hline \multirow[t]{11}{*}{ B } & $\mathrm{V}$ & ICP-MS & -0.03 & 0.03 & 0.15 & 0.05 & 0.57 & 0.05 & -0.62 & 0.52 & 2 & 0.026 & 100 \\
\hline & $\mathrm{Cr}$ & ICP-MS & 2.13 & 0.26 & 1.02 & 0.28 & 0.63 & 2.5 & 0.86 & 0.52 & 75 & 0.61 & 40 \\
\hline & Co & ICP-MS & 0.01 & 0.02 & 0.18 & 0.29 & 0.05 & 0.02 & 0.55 & 0.57 & 0 & 0.018 & 70 \\
\hline & $\mathrm{Ni}$ & ICP-MS & 0.82 & 0.14 & -0.16 & 0.11 & 0.22 & 0.63 & 1.31 & 0.40 & 68 & 0.58 & 100 \\
\hline & As & ICP-MS & -0.09 & 0.06 & 0.56 & 0.20 & 0.50 & 0.06 & -1.48 & 0.20 & 4 & 0.026 & 100 \\
\hline & $\mathrm{Se}$ & ICP-MS & 0.00 & 0.15 & 0.76 & 0.41 & 0.30 & 0.26 & 0.01 & 0.25 & 38 & 0.015 & 100 \\
\hline & $\mathrm{Cd}$ & ICP-MS & 6.28 & 0.28 & 10.4 & 7.9 & 0.18 & 6.5 & 0.96 & 10.3 & 13 & 0.028 & 20 \\
\hline & $\mathrm{Sn}$ & ICP-MS & 19.7 & 0.96 & 0.36 & 0.21 & 0.27 & 21.3 & 0.93 & 13.3 & 85 & 0.028 & 100 \\
\hline & $\mathrm{Sb}$ & ICP-MS & 22.2 & 3.58 & 3.9 & 1.63 & 0.42 & 30.6 & 0.72 & 16.0 & 94 & 0.026 & 100 \\
\hline & $\mathrm{Hg}$ & $\mathrm{Au}$ AAA & 0.64 & 0.06 & 24.9 & 24.1 & 0.12 & 0.69 & 0.94 & 0.34 & 87 & 0.001 & 40 \\
\hline & $\mathrm{Bi}$ & ICP-MS & -0.16 & 0.06 & 0.79 & 0.04 & 0.98 & 0.49 & -0.32 & 0.43 & 7 & 0.015 & 100 \\
\hline $\mathrm{C}$ & $\mathrm{Si}$ & & & & & & & & & & & & \\
\hline & $\mathrm{Cl}$ & & & & & & & & & & & & \\
\hline & $\mathrm{Pt}$ & & & & & & & & & 0.41 & 2 & & \\
\hline
\end{tabular}

\subsection{Q-ACSM}

A Q-ACSM (Aerodyne Inc., Billerica, MA, USA) was operated in the trailer housing the Xact 625 during the campaign. The Q-ACSM determines quantitative mass spectra of nonrefractory (NR) particles up to mass to charge ratios $(\mathrm{m} / \mathrm{z}$ ) of 150 (Crenn et al., 2015; Ng et al., 2011). Ion fragments were attributed mainly to organic aerosols, nitrate, sulfate, ammonium, and chloride, which comprise the reported data used in this study. The collection efficiency (CE) was determined for each spectrum according to Middlebrook et al. (2012), and its distribution peaked at the mode of $0.62( \pm 0.11) .293$ out of $1055 \mathrm{CE}$ values of the full ACSM dataset were equal to 0.45 . The Q-ACSM collected sub-micron $\left(\mathrm{PM}_{1}\right)$ particles and chemically analysed them in 30 min intervals, which were aggregated to $1 \mathrm{~h}$ averages for comparison with the Xact 625 data. All concentrations used in this study were CE corrected.

\section{$2.5 \quad 24 \mathrm{~h} \mathrm{PM} 10$ filter samples}

The $24 \mathrm{~h} \mathrm{PM}_{10}$ samples collected by the HiVol sampler on quartz filters were weighed at Empa laboratory in Dübendorf, Switzerland, to determine the gravimetric daily $\mathrm{PM}_{10}$ concentrations. These values were then used to correct the TEOM PM 10 concentrations on a daily basis. Therefore the
$24 \mathrm{~h}$ TEOM values correspond to $24 \mathrm{~h}$ gravimetric $\mathrm{PM}_{10}$. Ten $24 \mathrm{~h} \mathrm{PM}_{10}$ samples were analysed for their elemental composition at IDAEA-CSIC laboratory in Barcelona. A quarter of each filter was acid digested using a mix of $\mathrm{HF}: \mathrm{HNO}_{3}$ $(2.5: 1.25 \mathrm{~mL})$; the solution was kept in a Teflon reactor at $90^{\circ} \mathrm{C}$ for at least $6 \mathrm{~h}$, and after cooling $2.5 \mathrm{~mL}$ of $\mathrm{HClO}_{4}$ were added. The acid solution was brought to evaporation and the dry residual was re-dissolved with $\mathrm{HNO}_{3}$ and diluted with Milli-Q water for subsequent ICP-OES and ICPMS analysis. This method has been validated and used in many studies and is discussed in detail elsewhere (Minguillón et al., 2012; Querol et al., 2001, 2008). A total of 41 elements from $\mathrm{Li}$ to $\mathrm{U}$ were analysed: the major elements $\mathrm{Na}, \mathrm{Mg}, \mathrm{Al}, \mathrm{P}, \mathrm{S}, \mathrm{K}, \mathrm{Ca}$, Ti, and Fe with ICP-OES and the trace elements with ICP-MS. Si, Cl, and Pt were not analysed on the filters. Analyses of the reference material NIST 1633b (constituent elements in coal fly ash) using the same methodology as that for the samples yielded satisfactory results, with approximately $100 \%$ recoveries for the elements under study. Tests of the used methodology with respect to other ICP sample preparation and analysis methods, and applications of the methodology to NIST standards indicated the reliability of the method, exerting a maximum scatter of $10 \%$ for any of the elements, with most uncertainty values clearly below this limit. Relative uncertainties (precision) of 
the ICP measurements are less than $5 \%$ for the elements with concentrations well above their respective detection limits, whereas the overall uncertainty reflecting the entire sampling procedure, the digestion and the ICP analysis is on the order of $25 \%$. MDLs for ICP were determined according to Escrig et al. (2009), and the values for the elements relevant for our intercomparison are listed in Table $1 . \mathrm{Hg}$ was analysed with a $\mathrm{Hg}$ gold amalgamation atomic absorption analyser (AMA254, LECO instruments, Botasini et al., 2013; Diez et al., 2007). The three methods are referred to as the offline or ICP methods (ICP-OES, ICP-MS), and the Hg gold amalgamation atomic absorption spectrometry is abbreviated as AuAAA in this paper.

Three of the 10 filters were also analysed with a benchtop XRF system by CES, and with ICP-MS by an independent lab (Eastern Research Group, ERG, Research Triangle Park, NC, USA) to investigate inter-laboratory scatter. ERG used a different digestion method than IDAEA-CSIC. In addition, three filters were prepared with a reference aerosol of known concentration for $\mathrm{Fe}, \mathrm{Cu}, \mathrm{Zn}, \mathrm{Sr}$, and $\mathrm{Pb}$, which then were analysed by CES, IDAEA-CSIC, and ERG, again to gain insight into the inter-laboratory scatter. Details on these data and the methods are given in the supplement of this article.

\subsection{Data coverage and synchronization}

The Xact 625 measurements started on 23 July 2015 12:00 LT and ended on 13 August 2015 06:00 LT. The sampling interval was set to $1 \mathrm{~h}$. Two interruptions occurred during the sampling period: one due to an Xact 625 computer problem (33 h) and the other one due to a delayed filter tape change $(10 \mathrm{~h})$. The Xact dataset consists of 456 valid $1 \mathrm{~h}$ samples out of 499 possible samples, attaining a coverage of $91.4 \%$. The NABEL data were tailored to coincide with the Xact data. The 10 min TEOM PM 10 values were aggregated to $1 \mathrm{~h}$ values to synchronize them with hourly Xact 625 measurements. Additionally, the TEOM data were also adjusted to the gravimetrically determined $\mathrm{PM}_{10}$ masses from the HiVol filters to provide an independent reference for intercomparisons. The data used here contained some gaps, which were only partly synchronous for the selected parameters. Wind speed and direction missed 12 data points $(2.4 \%)$, precipitation $26(5.2 \%)$, and $\mathrm{PM}_{10} 53(10.6 \%)$ at hourly time resolution. The ACSM data contained a gap of $14.5 \mathrm{~h}$ due to software malfunction, which caused the data to be very noisy for that short period. These values were rejected from the analyses, and only the remaining 972 data points were averaged to $4651 \mathrm{~h}$ values, which then were resampled to the 456 Xact data points.

For the comparisons of the different instruments and sampling intervals, all data were resampled to the corresponding times of the Xact 625, according to the sub-classifications of the dataset (e.g. according to wind sectors). For the intercomparisons with the 10 filter samples, the hourly Xact data of the corresponding days were averaged to the $24 \mathrm{~h}$ of the filter samples. During each $24 \mathrm{~h}$ period, Xact generated $231 \mathrm{~h}$ values and $130 \mathrm{~min}$ value, which were aggregated to $24 \mathrm{~h}$ daily averages. This procedure implicitly assumes that the half-hour sample of the first sampling hour is representative for the whole hour. Tests with a $23.5 \mathrm{~h}$ weighted average yielded differences of less than $3 \%$ between the two calculation methods. Comparisons of hourly Xact data were only possible for $\mathrm{S}$ with the ACSM data (in the form of $\mathrm{PM}_{1}$ sulfate, assuming that all $\mathrm{S}$ occurs in $\mathrm{PM}_{1}$ ) and between the total Xact element mass and $\mathrm{PM}_{10}$ of the NABEL TEOM instrument; see Sects. 3.2 and 3.3.

\section{Results and discussion}

\subsection{Data validity derived from general statistics and MDLs}

The complete Xact dataset is visualized in Fig. 1, and general statistics are given in Table S1 in the Supplement. The salient feature of the concentration time series is the huge peak late on 1 August, caused by the National Day's fireworks episode. Further peaks before and after that day warranted dividing the full dataset into a fireworks period and a non-fireworks period. The fireworks period started on 31 July 2015 22:00 LT and lasted until 4 August 2015 11:00 LT, as will be discussed in more detail in Sect. 3.3. The remaining non-fireworks period is representative for the typical background concentrations at Härkingen and can be compared to literature values.

MDLs for the Xact 625 and for ICP-OES/MS and the $\mathrm{Hg}$ AuAAA method are listed in Table 1. Note that MDLs of elements measured by Xact 625 are based on $1 \mathrm{~h}$ sampling time while MDLs of filter-based elemental concentrations are based on $24 \mathrm{~h}$. Generally, values below $3 \times \mathrm{MDL}$ are expected to have much higher uncertainty. Hence, elements with more than $80 \%$ of the data below $3 \times$ MDL were rejected from further examination. Xact $625 \mathrm{MDLs}$ have not been determined by the manufacturer for $\mathrm{Si}, \mathrm{S}$, and $\mathrm{Cl}$, because self-absorption effects for elements lighter than $\mathrm{Ca}$ become more important with decreasing atomic number (Formenti et al., 2010). However, these three elements are abundant, and we assume that they are well above their Xact detection limit. For these elements, an ICP MDL is only given for $\mathrm{S}$, because $\mathrm{Si}$ cannot be determined in the filter samples, as it is a main constituent of the quartz filters and is also digested during sample preparation, and $\mathrm{Cl}$ cannot be determined by ICP. The table indicates the amount of data points $>$ MDL in percent for the different analysis methods. The elements K, Ca, Ti, Mn, Fe, Cu, Zn, Sn, Sb, Ba, and $\mathrm{Pb}$ have most values above the MDL, and their measurement should thus be reliable. Seven Xact elements have $>50 \%$ of their data points below MDL and more than $90 \%$ below 3*MDL: V, Co, As, Se, Cd, Pt, and Bi. $\mathrm{Cr}$ and $\mathrm{Cd}$ show the same behaviour for ICP. Ni revealed variable blank con- 


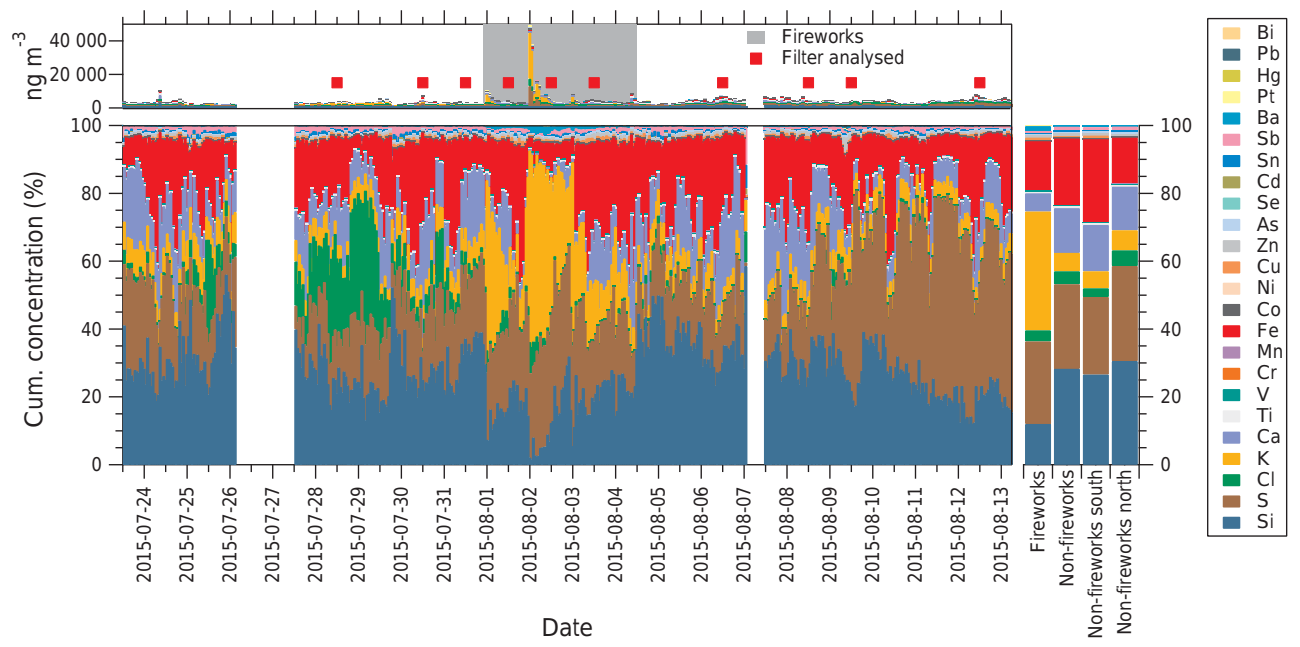

Figure 1. Main panel: relative amount of analysed elements by Xact 625 during the field campaign. Top panel: absolute concentrations, stacked. The grey shaded area denotes the fireworks period. The red squares mark the days when $24 \mathrm{~h}$ filters were analysed and used for comparisons in this study. Bottom panel: relative cumulative elemental concentrations, stacked. Right panel: average relative contributions (in \%) of elements for the fireworks period, the non-fireworks period, and the south and north sectors during the non-fireworks period.

centrations in the filters and could therefore not be reliably measured with ICP. $\mathrm{Hg}$ is also mostly below MDL in the AuAAA measurement, and $\mathrm{Pt}$ was not measured with ICP at all. In summary, 11 elements $(\mathrm{K}, \mathrm{Ca}, \mathrm{Ti}, \mathrm{Mn}, \mathrm{Fe}, \mathrm{Cu}, \mathrm{Zn}$, $\mathrm{Sn}, \mathrm{Sb}, \mathrm{Ba}, \mathrm{Pb}$ ) are above their MDLs for both the XRF and the offline methods, 7 elements (V, Co, As, Se, Cd, Pt, Bi) are below MDL for the XRF, and 3 elements $(\mathrm{Cr}, \mathrm{Cd}, \mathrm{Hg}$ ) are below MDL for the offline methods (of which only $\mathrm{Cd}$ is below MDL for both XRF and ICP).

The comparisons between online Xact 625 and offline $24 \mathrm{~h}$ $\mathrm{PM}_{10}$ elemental concentrations for 21 elements are shown in Figs. 2, 3, and Table 1. Only the 21 elements analysed by both methods are compared by dividing them into two groups based on data characteristics.

Group A shows excellent correlations between the two measurement methods $\left(r^{2}\right.$ values $\left.>0.95\right)$ and intercepts $<40 \%$ of mean concentration and consists of the elements $\mathrm{S}, \mathrm{K}, \mathrm{Ca}, \mathrm{Fe}$ (analysed by ICP-OES), Ti, $\mathrm{Mn}, \mathrm{Cu}$, $\mathrm{Zn}, \mathrm{Ba}$, and $\mathrm{Pb}$ (analysed by ICP-MS). The regression intercepts were not forced to be zero to enable examination of potential differences in the measurement accuracy of each of the compared methods, e.g. blank subtraction. The slopes are more relevant and indicate biases between the methods. Orthogonal least-squares regressions metrics were calculated, which incorporates measurement errors in both quantities being compared. The slopes differed by less than $3.5 \%$ between the two regression methods for the Group A elements. Ba and $\mathrm{Pb}$ achieved an almost perfect match with slopes around 1 and negligible intercepts. The other extreme is $\mathrm{Zn}$ with a slope of 1.8. Ti is another peculiar case with a slope of 1.13 and the largest intercept/average concentration ratio of 0.37 . On average, the Xact 625 yielded approximately $28 \%$ higher elemental concentrations than ICP for the Group A elements.
The high linearity and little scatter in the regressions testify for the precision of both the Xact and the ICP methods, but the differences in the slopes (range 0.97 to 1.8 ) for different elements require further investigation. No systematic deviations based on elemental molecular weight or X-ray excitation conditions were observed in these slopes. The deviations of the slopes from unity may be partially attributed to the different inlets for the Xact and the HiVol samplers (Panteliadis et al., 2012), which may produce a difference in collected mass on the order of $10 \%$. The inlets were not explicitly tested for their cut-off characteristics in this study. A slightly different cut-off value for the particle size may lead to differences in the collected mass, especially for the largest and heaviest particles in $\mathrm{PM}_{10}$, and hence to an underestimation or overestimation of the total mass collected with a particular inlet. This may be of special relevance in a near-road setting with lots of re-suspended dust (ACES, 2012). Potential line interference between $\mathrm{Ti}$ and $\mathrm{Ba}$ can be excluded, because the element couple reveals two different regressions for fireworks and non-fireworks cases, as well as distinct diurnal variations in the non-fireworks cases.

The results of additional investigations of a few selected filters by independent labs and analytical methods for understanding these differences are discussed in the supplementary material. Examination of reference samples indicated a high precision in XRF measurements despite consistently underestimated absolute concentration (underestimated by 6 to $14 \%$ depending on the element). In contrast, ICP measurements indicated greater variability (range of $30 \%$ underestimation to $60 \%$ overestimation, depending on the element) and hence higher uncertainty in estimated ambient concentrations. Examination of three filter samples collected during the campaign by an offline XRF instrument (by CES) and by 


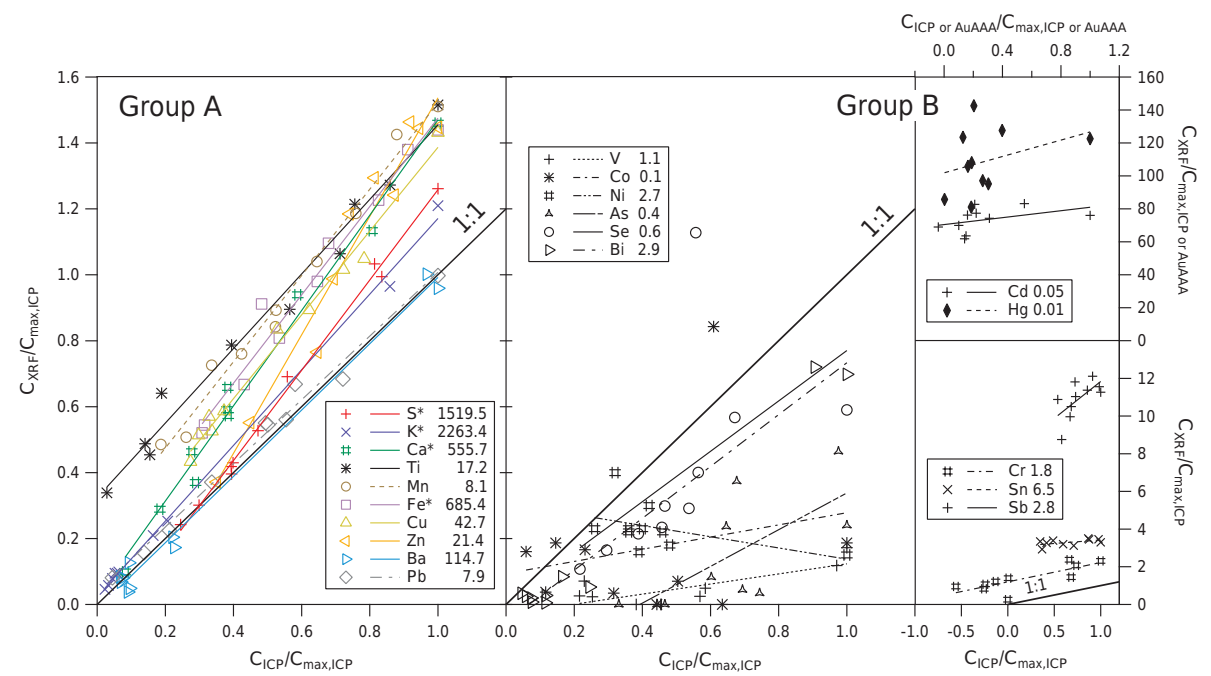

Figure 2. Scatter plots and regression lines of Xact 625 (ordinate) vs. ICP-OES/MS (abscissa) data for groups A and B. Elements with an asterisk $\left(^{*}\right)$ were analysed with ICP-OES. The axes have been scaled by the maximum concentration $C_{\text {max.ICP indicated in the legends for }}$ each element $\left(C_{\text {max }}\right.$,AuAAA for $\mathrm{Hg}$ ). The Levenberg-Marquardt linear least-squares fitting method was applied, taking the ICP measurements as the independent data. Regression equation is $y=\mathrm{a}+b x$. See Table 1 for data.

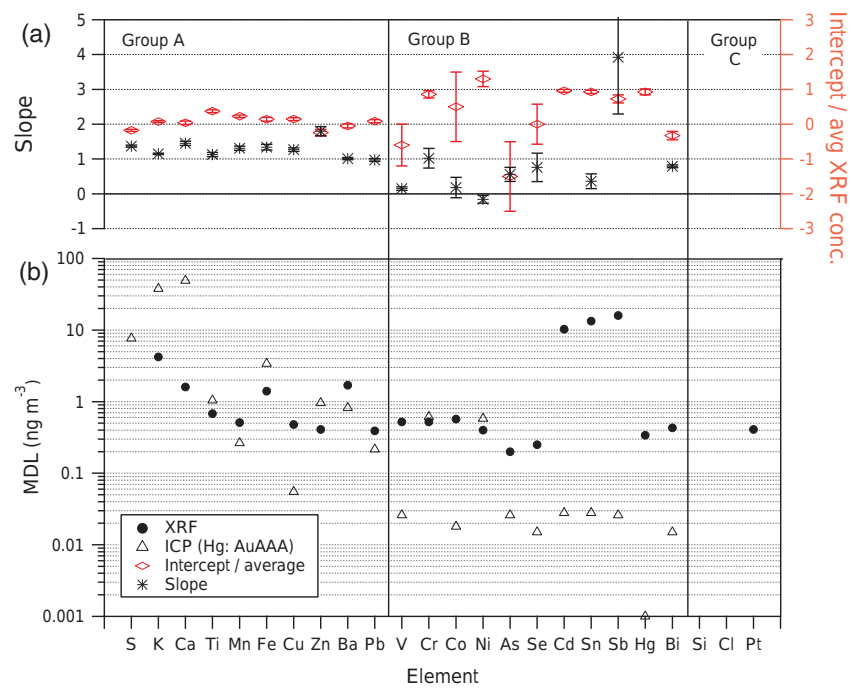

Figure 3. (a) Slopes and intercept ratios (intercepts divided by the average concentrations measured with $\mathrm{XRF}$ ) with standard deviations for all elements measured with the Xact. (b) Minimum detection limits (MDL), interference free for the Xact 625 (XRF) and for the ICP analyses. Hg was analysed with AuAAA spectrometry.

ICP at an external laboratory (ERG) indicated a variability of about $30 \%$ for most elements, an almost perfect match $(-0.1 \%)$ between ICP labs for the average concentrations when $\mathrm{Ca}$ and $\mathrm{Se}$ are excluded, and deviations of less than $5 \%$ between benchtop XRF and ICP (Table S2). These results are comparable to those in Gerboles et al. (2011). Comparisons between the Xact and benchtop XRF in previous tests by the manufacturer with better control of the sampler inlet condi- tions almost always were within $5 \%$ of each other. The relative mean difference of $28 \%$ between Xact and filter data (analysed with ICP) for samples collected during the field campaign appears to be systematic. Such differences may result from a difference in location of the Xact and filter sampling inlets $(\sim 5 \mathrm{~m})$ and their relative distance from the freeway. Ultrafine particle number concentrations from dust resuspension due to vehicle traffic are known to decrease with increasing distance from the road, with the sharpest decline observed within the first $50 \mathrm{~m}$ (Hagler et al., 2009). Crustal elements, which dominate in the $\mathrm{PM}_{10}$ size fraction, are expected to settle faster due to larger aerosol size. Hence the difference in Xact- and ICP-reported $\mathrm{PM}_{10}$ elemental concentrations may be indicative of a gradient in PM occurring for some elements in close proximity to roadways. To quantify such near-source PM gradient, a field campaign with a different design would be needed, e.g. an array of samplers along a line perpendicular to the freeway. However, since the difference is also observed for $\mathrm{S}$, which is typically found in the fine mode, does not have a major traffic related source apart from coarse re-suspended dust, and is not expected to suffer from incomplete digestion we assign part of the differences also to calibration issues with Xact.

Group B, the remainder, consists of the elements $\mathrm{V}, \mathrm{Cr}$, $\mathrm{Co}, \mathrm{As}, \mathrm{Se}, \mathrm{Cd}$, and $\mathrm{Bi}$, i.e. of those elements that are close to or below their Xact MDL, plus $\mathrm{Ni}, \mathrm{Cd}, \mathrm{Sn}, \mathrm{Sb}$, and $\mathrm{Hg}$. Ni, $\mathrm{Cd}$, and $\mathrm{Hg}$ were below MDL for the offline methods (Cd for Xact and offline methods). Although an intercomparison of these elements may not be justified, we observed some features in the regressions of the Group B elements in Fig. 2 that are worth commenting. $\mathrm{Cr}$ is below the ICP-MS MDL for $60 \%$ and below $3 * \mathrm{MDL}$ for all filter values, but $75 \%$ 
Table 2. Comparison of Xact data with published ICP data of other campaigns.

\begin{tabular}{|c|c|c|c|c|c|c|c|c|c|c|c|}
\hline \multirow[t]{6}{*}{ Group } & & \multirow{2}{*}{$\begin{array}{r}\text { Xact } 625 \text { averages } \\
\text { Non-fireworks } \\
\text { days }\end{array}$} & \multicolumn{9}{|c|}{ Filter samples } \\
\hline & & & Belp & Geneva & $\begin{array}{r}\text { Basel, } \\
\text { summer }\end{array}$ & Payerne & Zürich & $\begin{array}{l}\text { Zürich, } \\
\text { summer }\end{array}$ & $\begin{array}{l}\text { Payerne, } \\
\text { summer }\end{array}$ & $\begin{array}{l}\text { Payerne, } \\
\text { summer }\end{array}$ & $\begin{array}{l}\text { Härkingen } \\
\text { NABEL }\end{array}$ \\
\hline & Reference & & 1 & 2 & 3 & 4 & 5 & 6 & 6 & 7 & 8 \\
\hline & No. cases, size & 17 & $\mathrm{PM}_{8}$ & $\mathrm{PM}_{10}$ & $\mathrm{PM}_{10}$ & $\mathrm{PM}_{10}$ & $\mathrm{PM}_{10}$ & $\mathrm{PM}_{10}$ & $\mathrm{PM}_{10}$ & $\mathrm{PM}_{10}$ & $\mathrm{PM}_{10}$ \\
\hline & Sampling period & 2015 & $1985 / 86$ & $1996 / 97$ & $1997 / 98$ & $1998 / 99$ & $2008 / 09$ & 2009 & 2009 & 2012 & 2015 \\
\hline & Unit & $\mathrm{ng} \mathrm{m}^{-3}$ & $\mathrm{ng} \mathrm{m}^{-3}$ & $\mathrm{ng} \mathrm{m}^{-3}$ & $\mathrm{ng} \mathrm{m}^{-3}$ & $\mathrm{ng} \mathrm{m}^{-3}$ & $\mathrm{ng} \mathrm{m}^{-3}$ & $\mathrm{ng} \mathrm{m}^{-3}$ & $\mathrm{ng} \mathrm{m}^{-3}$ & $\mathrm{ng} \mathrm{m}^{-3}$ & $\mathrm{ng} \mathrm{m}^{-3}$ \\
\hline \multirow[t]{10}{*}{ A } & $S$ & 790 & & & & & 2394 & 625 & 637 & 360 & \\
\hline & $\mathrm{K}$ & 167 & & & 630 & 98 & 1318 & 187 & 188 & 120 & \\
\hline & $\mathrm{Ca}$ & 398 & & & 720 & 100 & 137 & 451 & 355 & 180 & \\
\hline & $\mathrm{Ti}$ & 11.3 & & & 38 & & 6.5 & 13.9 & 14.3 & 9.9 & \\
\hline & $\mathrm{Mn}$ & 7.2 & 31.7 & & 16 & 2.8 & 5.8 & 7.2 & 5 & 2.8 & \\
\hline & $\mathrm{Fe}$ & 594 & & & 760 & 89 & 390 & 455 & 202 & 130 & \\
\hline & $\mathrm{Cu}$ & 24.4 & 7.9 & 35 & 75 & 6 & 28.1 & 17.4 & 4.3 & 2.8 & 19.7 \\
\hline & $\mathrm{Zn}$ & 19.0 & 65.0 & 120 & 73 & & 20.3 & 16.1 & 9.4 & 7.5 & \\
\hline & $\mathrm{Ba}$ & 7.1 & & & 110 & & 6.7 & 6.5 & 3.9 & 1.8 & \\
\hline & $\mathrm{Pb}$ & 3.0 & 134 & 95 & 51 & 10 & 14.2 & 3.6 & 3.1 & 1.2 & 4.9 \\
\hline \multirow[t]{11}{*}{ B } & $\mathrm{V}$ & 0.06 & 3.9 & & & 0.7 & 0.4 & 1.0 & 1.2 & 0.7 & \\
\hline & $\mathrm{Cr}$ & 2.4 & & & 8 & & 0.9 & 2.3 & 1.6 & 1.0 & \\
\hline & Co & 0.02 & & & & & 2.6 & 0.1 & 0.1 & & \\
\hline & $\mathrm{Ni}$ & 0.63 & & & 8 & 1.2 & 0.6 & 0.9 & 1.0 & 0.5 & 0.9 \\
\hline & As & 0.02 & 2.2 & 2 & 1 & 0.53 & & 0.3 & 0.5 & 0.2 & 0.31 \\
\hline & $\mathrm{Se}$ & 0.30 & & 6 & & 0.16 & & 0.3 & 0.3 & 0.2 & \\
\hline & $\mathrm{Cd}$ & 6.7 & 0.88 & 0.4 & 0 & 0.32 & & 0.1 & 0.1 & & 0.07 \\
\hline & Sn & 20.9 & & & & & 2.6 & 2.6 & 1.0 & & \\
\hline & $\mathrm{Sb}$ & 31.6 & & & 29 & 0.26 & 2.5 & 2.4 & 0.5 & & \\
\hline & $\mathrm{Hg}$ & 0.64 & & 0.5 & & & & & & & \\
\hline & $\mathrm{Bi}$ & 0.07 & & & & & & 0.2 & 0.1 & & \\
\hline \multirow[t]{3}{*}{$\mathrm{C}$} & $\mathrm{Si}$ & 829 & & & & & 211 & 571 & 634 & 370 & \\
\hline & $\mathrm{Cl}$ & 109 & & & 41 & & 657 & 66 & 190 & 30 & \\
\hline & $\mathrm{Pt}$ & 0.05 & & & & & & & & & \\
\hline
\end{tabular}

1: Gälli Purghart et al. (1990). 2: Chiaradia and Cupelin 2000 - fortnight averages. 3: Röösli et al. (2001). 4: Hueglin et al. (2005). 5: Richard et al. (2011). 6: Minguillón et al. (2012). 7: Alastuey et al. (2016). 8: BAFU and Empa (2015) - annual mean values.

are above the Xact MDL. The ICP measurement is below MDL because of the high and variable blank concentrations, which make a meaningful blank subtraction difficult and increase the Cr MDL in these samples. Although the slope of $\mathrm{Cr}$ is 1.23 and thus comparable to the other Group A slopes, a comparison with ICP values is statistically not robust. However, $\mathrm{Cr}$ seems to be quantifiable with the Xact. The regression plot of Bi shows two extreme values on 31 July and 1 August corresponding to the fireworks days. These two points are above MDL for both methods and suggest good quantitative agreement between XRF and ICP for these two high-concentration cases. Sb shows a moderate correlation $\left(r^{2}=0.47\right)$ and a large intercept. Sn behaves similarly as $\mathrm{Sb}$, with an $r^{2}$ value of 0.15 . The large intercepts hint toward a problem in processing the Xact blanks. In addition, when $\mathrm{Ca}$ is abundant, as in our case in Härkingen, the $\mathrm{Sb} \mathrm{L} \alpha$ line interferes with the $\mathrm{Ca} \mathrm{K} \alpha$ line, producing low signal-to-noise ratios for $\mathrm{Sb}$, and similarly for the pair $\mathrm{K}-\mathrm{Sn}$. Hence, the reported Xact concentrations of $\mathrm{Sn}$ and $\mathrm{Sb}$ reflect mainly spectral noise. Of the filter $\mathrm{Hg}$ data, $60 \%$ were below MDL and thus cannot be compared well with the Xact Hg data. Inspection of the Xact raw $\mathrm{Hg}$ spectra showed a possible interfer- ence from $\mathrm{Br}$ causing the fitting routine to attribute some $\mathrm{Br}$ mass to non-existent $\mathrm{Hg}$ peaks in the spectra. $\mathrm{Br}$ was not calibrated in the fitting routine. Thus the $\mathrm{Hg}$ concentrations reported by the Xact seem to be due to this interference and are not realistic, even though $86 \%$ of the measured values are above the Xact MDL. Values $<1.5 \mathrm{ng} \mathrm{m}^{-3}$ are in the same order of magnitude as the fortnight values of Chiaradia and Cupelin (2000) for the city of Geneva (Table 2). The element couples of $\mathrm{Fe}-\mathrm{Co}$ and $\mathrm{Pb}-\mathrm{As}$ do not show correlations within the couples because most of their data points are below their respective MDLs, and no conclusion about the deconvolution of interfering lines can be drawn for these elements. Comparing the Xact values with the NABEL annual mean values (Table 2) shows differences smaller than $40 \%$ for $\mathrm{Cu}$, $\mathrm{Pb}$, and $\mathrm{Ni}$, while the differences are much larger for As and $\mathrm{Cd}$. The latter two elements are below their respective MDL (Fig. 2). To summarize, the Group B elements show issues with the MDLs of at least one of the analysis methods, which restricts thorough interpretation. Individual data points above MDL reveal nevertheless a usable quantification by the Xact in these particular cases. Determination of $\mathrm{Sb}, \mathrm{Sn}$, and $\mathrm{Hg}$ by Xact is potentially impacted by XRF line interferences 
and warrants further improvements for better quantification by Xact.

The Group C elements $\mathrm{Si}, \mathrm{Cl}$, and $\mathrm{Pt}$ were not measured on the filters. An Xact MDL for S has not yet been determined. Data quality of $\mathrm{S}$ measurements was inferred by comparing its Xact concentrations with the concentrations of another element originating from the same source or belonging to the same chemical compound. Xact-reported $\mathrm{S}$ (with unknown MDL) and $\mathrm{K}$ (with known MDL) concentrations were highly correlated $\left(r^{2}=0.99\right)$ during the fireworks period, with a slope of $2.30 \pm 0.05$, which agrees with the stoichiometric relation between $\mathrm{K}$ and $\mathrm{S}$ when forming $\mathrm{K}_{2} \mathrm{SO}_{4}$. For the non-fireworks periods the correlation was weak $\left(r^{2}=0.16\right)$, which hints towards a completely different, more random relationship between the two elements, as expected. Hence, high-concentration $\mathrm{K}$ reported by the Xact provided reliable $\mathrm{S}$ during the fireworks episode, despite the lack of an established MDL for S. Xact Pt measurements were always below MDL, and no conclusion about the Pt accuracy can be drawn.

\subsection{Comparisons with other data}

Figure 1 shows that roughly $95 \%$ of the total analysed elemental mass by Xact is comprised of six elements: $\mathrm{Si}, \mathrm{S}$, $\mathrm{Cl}, \mathrm{K}, \mathrm{Ca}$, and $\mathrm{Fe}$. These major elements all show average concentrations $>100 \mathrm{ng} \mathrm{m}^{-3}$. Si, S, Ca, and Fe are observed throughout the study, although with high variability. $\mathrm{Cl}$ and $\mathrm{K}$ are abundant only episodically: $\mathrm{Cl}$ is strongly tied to westerly winds during the last week of July and is practically absent after 2 August. $\mathrm{K}$ is prominent during the fireworks period. $\mathrm{Ti}, \mathrm{Cu}$, and $\mathrm{Zn}$ show daily average concentrations between 11 and $34 \mathrm{ng} \mathrm{m}^{-3}$. The other analysed elements were found in daily average concentrations $<10 \mathrm{ng} \mathrm{m}^{-3}$. The concentrations are of the same order of magnitude as those recently measured at other places in Switzerland, e.g. at an urban background site in Zurich (Minguillón et al., 2012; Richard et al., 2011, Table 2), but are generally lower than the measurements in older studies (Chiaradia and Cupelin, 2000; Gälli Purghart et al., 1990; Röösli et al., 2001, Table 2). The decreasing trends in PM and trace element concentrations have been documented in numerous NABEL reports on the air quality in Switzerland (e.g. BAFU and Empa, 2015; Gianini et al., 2012). These trends make it preferable to use modern studies for comparisons. Furthermore, the episodic nature of the 2015 campaign also demands for some generosity when comparing the measured values with annual or seasonal mean values.

A time series of the Xact 625 total element concentrations together with the NABEL TEOM PM 10 data and the total ACSM NR-PM 1 concentrations with $1 \mathrm{~h}$ resolution is presented in Fig. 4. The total ACSM NR-PM 1 concentration is the sum of sulfates, nitrates, ammonia, chlorides. and organic aerosols. Total $\mathrm{PM}_{10}$ shows a generally increasing trend over the whole campaign, with a strong peak superposed on 1 August 2015, whose increase coincides with the

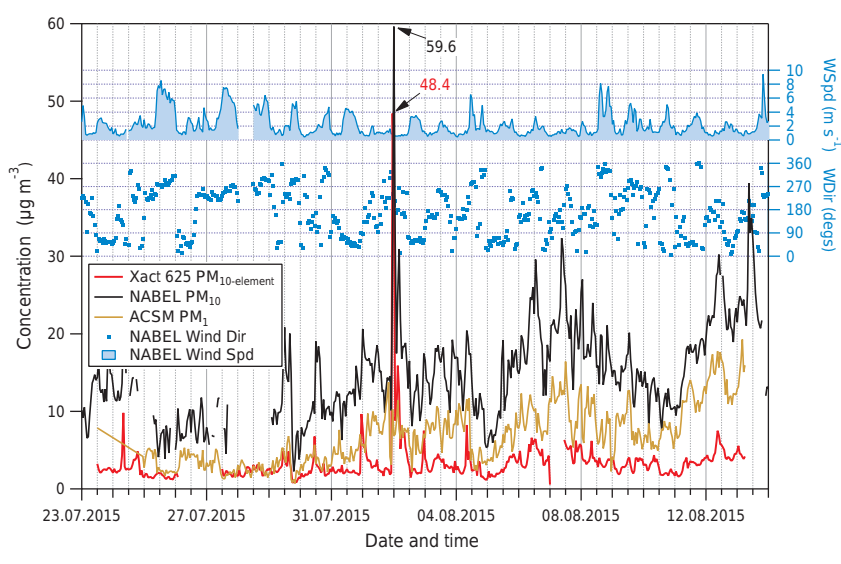

Figure 4. Time series of Xact 625 total elemental concentration, ACSM PM1 data, NABEL TEOM PM 10 data, and wind speed (WSpd) and direction (WDir) measurements in Härkingen. Numbers at the peaks indicate $1 \mathrm{~h}$ concentration maxima.

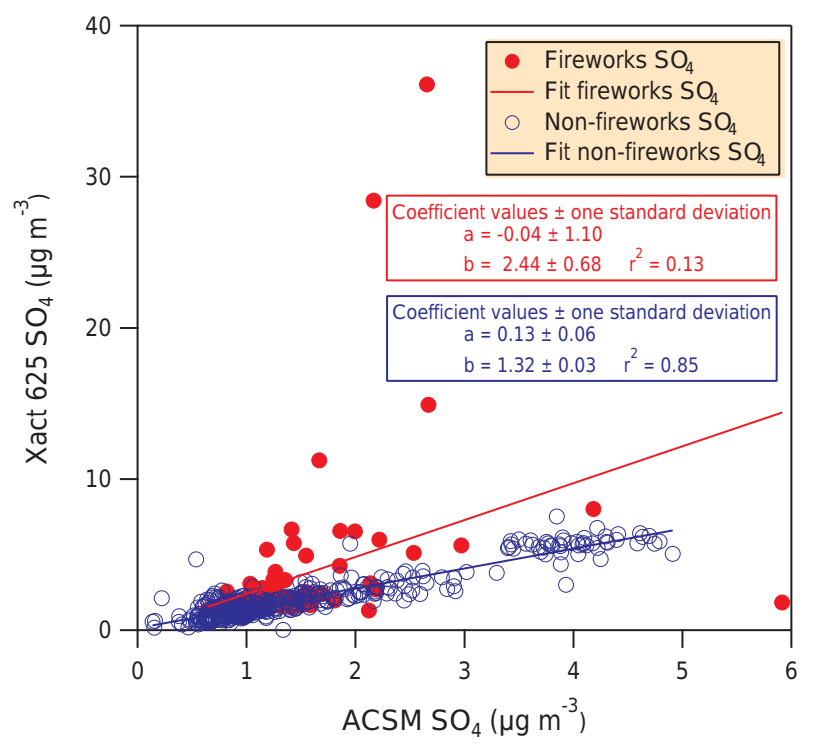

Figure 5. Comparison of Xact $\mathrm{PM}_{10} \mathrm{SO}_{4}$ vs. ACSM $\mathrm{PM}_{1} \mathrm{SO}_{4}$. Data were split into fireworks (red) and non-fireworks (blue) periods.

peak in the Xact data, whereas the maximum is delayed by $1 \mathrm{~h}$ relative to the Xact data. The peak is due to the fireworks burnt on that evening. On average the Xact 625 elements make up about $20 \%$ of the total $\mathrm{PM}_{10}$ mass (regression slope $0.2, r^{2}=0.63$ ). A complete mass closure cannot be achieved because the NABEL station only reports the total gravimetric $\mathrm{PM}_{10}$ mass and $\mathrm{PM}_{2.5} \mathrm{EC}$ concentrations with diurnal or better time resolution.

Xact's measurement accuracy for $\mathrm{S}$ was tested by comparison with ACSM sulfate measurements (Fig. 5) performed at $1 \mathrm{~h}$ resolution. The $\mathrm{S}$ concentrations of Xact 625 were multiplied with a factor of 3 , assuming that all $\mathrm{S}$ occurred in the form of $\mathrm{SO}_{4}^{2-}$. The slope of the regression line for the 
non-fireworks case is 1.34 , with $r^{2}=0.85$, in line with the Group A elements and in agreement with the comparison of $\mathrm{S}$ from Xact and from ICP; hence the slope between ACSM $\mathrm{SO}_{4}$ and ICP $\mathrm{SO}_{4}$ would be $\sim 1$. The high linear correlation suggests a high precision of the Xact 625 data but does not allow a definitive answer on the accuracy because of expected self-absorption effects, which would increase the slope further if corrected. During the fireworks period, the scatter is large, and the correlation coefficient is only 0.1 . We hypothesize that fireworks produce larger and non-refractory particles (e.g. $\mathrm{K}_{2} \mathrm{SO}_{4}$ ) not measured by the ACSM.

In summary, the on average 25 to $30 \%$ difference between the Xact and ICP data can probably be explained by differences in the sampling inlets, the distance between the inlets, and uncertainties of the different analysis methods. The correlation coefficients close to 1 for many elements demonstrate the high precision of the Xact and ICP methods. The obtained time series of those elements can thus reliably be used for source apportionment. The subsequent analyses (e.g. elemental concentration ratios, enhancement ratios) were done with the unmodified Xact data. The only exception is estimation of a mass budget in the discussion of the extreme concentrations in Sect. 3.3.

\subsection{Extreme concentrations: the fireworks period}

As mentioned in Sect. 3.1 the measurement campaign can be divided into a fireworks and a non-fireworks period. A K concentration $>220 \mathrm{ng} \mathrm{m}^{-3}$ served as the criterion to distinguish between these periods, and we required the fireworks period to be contiguous from the first increase in K on 31 July 2015 22:00 LT to the final decay to background values on $4 \mathrm{Au}-$ gust 2015 11:00 LT. The average K concentration during the fireworks period was $2 \mu \mathrm{g} \mathrm{m}^{-3}$, but this period showed extremely high hourly $\mathrm{PM}_{10}$ concentrations and an element mix different from the remainder of our test campaign.

Investigation of the highest peaks reveals the performance of the Xact under high load conditions, when sample thickness may become critical for XRF analysis. A comparison of the two instruments' peaks could demonstrate how closely the Xact mass represents the total measured PM $_{10}$ mass. Inspection of the different time series indicates that the TEOM peak is broader $(3 \mathrm{~h})$ and higher $\left(60 \mu \mathrm{g} \mathrm{m}^{-3}\right)$, and its maximum concentration is reached $1 \mathrm{~h}$ later (at 2 August 2015 00:00 LT), but its increase in concentration starts at the same time as the Xact (at 22:00 LT). The delay in the maximum can be attributed to the time constant of the TEOM used for reducing measurement noise and to the averaging procedure. For a comparison of the two peaks their measured masses were integrated over the duration of the peaks, i.e. over $2 \mathrm{~h}$ for the Xact data and the ACSM data and $3 \mathrm{~h}$ for the NABEL data. The integrated NABEL PM 10 mass reached a concentration of $122 \mu \mathrm{g} \mathrm{m}^{-3}$. The Xact 625 monitor reported a total of $86 \mu \mathrm{g} \mathrm{m}^{-3}$ for the sum of all analysed elements (except Pd, which was used only as an internal standard).
The bulk of this concentration $\left(84 \mu \mathrm{g} \mathrm{m}^{-3}\right)$ was made up of a few elements (in parentheses: concentrations in $\mu \mathrm{g} \mathrm{m}^{-3}$, and abundances relative to total analysed element mass,

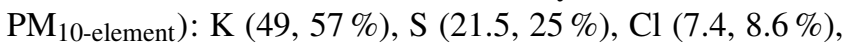
$\mathrm{Fe}(3.2,3.7 \%)$, Ba $(2.1,2.4 \%)$, and $\mathrm{Si}(1.7,1.9 \%)$. Absolute $\mathrm{K}$ and $\mathrm{S}$ concentrations are in good agreement with the values in Drewnick et al. (2006). K likely originated from $\mathrm{KNO}_{3}$, a basic constituent of black powder (Drewnick et al., 2006; Kong et al., 2015).

The ACSM PM 1 contributed $20.5 \mu \mathrm{g} \mathrm{m}^{-3}$ (17\%) to the aerosol concentration in the fireworks peak.

The comparison of the Xact concentration and the TEOM $\mathrm{PM}_{10}$ concentration for the 1 August peak requires taking into account the systematic difference between the Xact and TEOM measurements discussed above and the fact that the elements are typically not present in elemental but rather in their oxidized form, such that the mass of the latter needs to be included for a quantitative comparison. We therefore estimate a mass budget for the fireworks peak, when the six elements $\mathrm{K}, \mathrm{S}, \mathrm{Cl}, \mathrm{Fe}, \mathrm{Ba}$, and $\mathrm{Si}$ comprise the bulk of the total mass. We calculate the ion balance for the positive ions $\mathrm{K}^{+}, \mathrm{Fe}^{2+}, \mathrm{Ba}^{2+}, \mathrm{Si}^{2+}$, and submicron $\mathrm{NH}_{4}^{+}$and negative ions $\mathrm{Cl}^{-}, \mathrm{SO}_{4}^{2-}$, and submicron $\mathrm{NO}_{3}^{-}$. We further add all available components from the NABEL station $\left(\mathrm{PM}_{2.5}\right.$ equivalent black carbon, eBC) and the ACSM $\left(\mathrm{NO}_{3}, \mathrm{NH}_{4}\right.$, and organic aerosols, but not $\mathrm{SO}_{4}$, as this is already considered with the $\mathrm{S}$ in the Xact data) to the mass balance. Using the measured values of the Xact 625 yields an excess of negative ions of $2.7 \%$ and a total mass of $141 \mu \mathrm{g} \mathrm{m}^{-3}$, which overestimates the TEOM value of $122 \mu \mathrm{g} \mathrm{m}^{-3}$ by $16 \%$. If Xact concentrations were scaled towards the ICP concentrations with the corresponding regression slopes from Table 1, using for $\mathrm{Cl}$ and $\mathrm{S}$ the average slope of 1.22 from the other four elements, then the calculation yields an excess of $11 \%$ in positive ions, which are then assumed to be neutralized by oxygen. This yields a total mass of $116 \mu \mathrm{g} \mathrm{m}^{-3}$, which is $4.6 \%$ lower than the TEOM value. Our values are lower limits of the total mass because the balance is incomplete with respect to relevant elements in the fireworks (e.g. Sr) and other chemical species like carbonaceous and nitrogen containing molecules in the coarse fraction. The result shows that the bulk of fireworks $\mathrm{PM}_{10}$ aerosols are a few metals oxidized to sulfates, chlorides, and oxides. Overall, these results further demonstrate the advantage of Xact's high-timeresolution sampling for associating high-metal-concentration episodes with source emission activities.

\subsection{Investigation of sources}

Trace elements can be excellent tracers for specific aerosol sources (e.g. Hopke, 2016; Park et al., 2014; Querol et al., 2007; Visser et al., 2015a). A simple approach for characterizing a common source for a group of elements is to study the temporal covariation of the elements in this group. For our Härkingen data, the time series indicate the strong influ- 

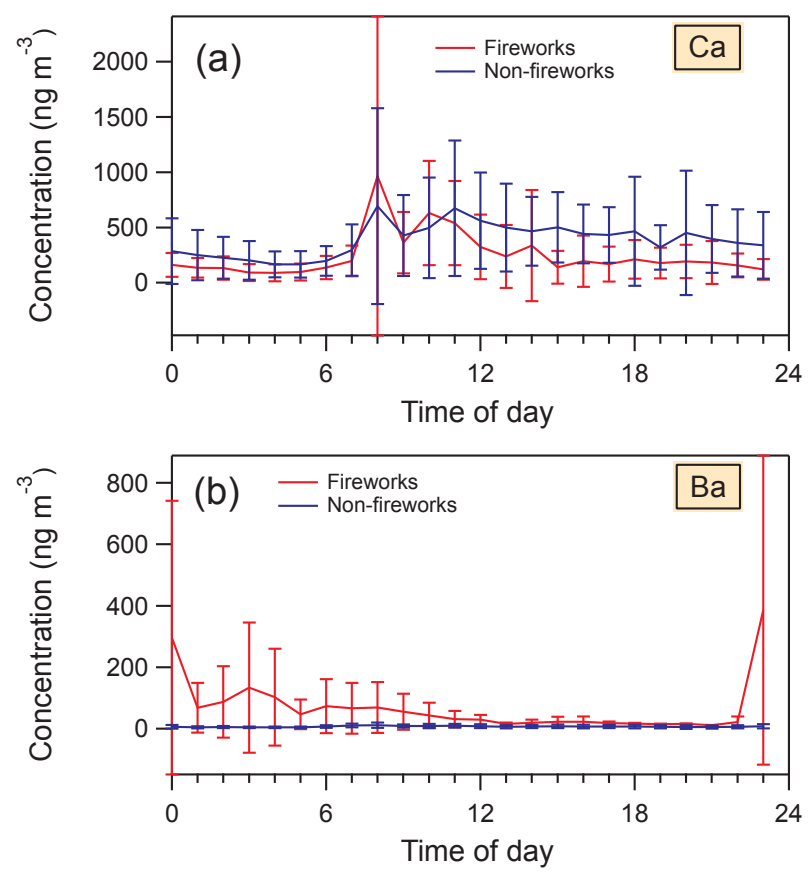

Figure 6. Mean diurnal variations of (a) $\mathrm{Ca}$ and (b) $\mathrm{Ba}$, stratified for fireworks (red) and non-fireworks (blue) periods. Error bars denote \pm 1 standard deviation of the averaging period. Diurnal variations for the other elements are shown in the Supplement (Fig. S4).

ence of the fireworks on the concentrations of $\mathrm{K}, \mathrm{S}, \mathrm{Ti}, \mathrm{Cu}$, and $\mathrm{Ba}$ (Figs. 6 and 7), which are important constituents of fireworks along with $\mathrm{Sr}$ as fireworks tracer (Kong et al., 2015; Moreno et al., 2007). Examination of a few raw spectra from the fireworks and non-fireworks periods indeed identified an enhancement of $\mathrm{Sr}$ during the fireworks duration, while the peak was definitively absent during the non-fireworks period. $\mathrm{Sr}$ was, however, not quantified in our configuration, as we put emphasis on crustal elements and some special trace elements difficult to detect in Switzerland ( $\mathrm{Hg}, \mathrm{Pt}$ ).

The $1 \mathrm{~h}$ sampling interval further enabled examination of diurnal variations of the elements. $\mathrm{Ca}$ and $\mathrm{Ba}$ are presented in Fig. 6 and the other elements in Fig. S4, which shows the classification of the data according to fireworks and nonfireworks periods. It can be seen for the time from 23:00 to $06: 00$ that the elements $\mathrm{Ba}, \mathrm{Bi}, \mathrm{Cu}, \mathrm{K}, \mathrm{S}$, and $\mathrm{Ti}$ show a clear distinction between the two periods. The fireworks elements show a maximum concentration at 23:00 LT and a gradual decay over the next 6 to $12 \mathrm{~h}$ into the morning hours of the (following) day. $\mathrm{Mn}, \mathrm{Fe}$, and $\mathrm{Zn}$ also show an increased and then decaying concentration after midnight, but the difference compared to non-fireworks days is within the data variability. $\mathrm{Si}$ is depleted during the fireworks period relative to the non-fireworks period. This is probably a weekday vs. weekend effect, when fewer HDV circulate (Switzerland does not permit HDV use on Sundays) and less road dust is re-suspended (Bukowiecki et al., 2009, 2010). For the non-

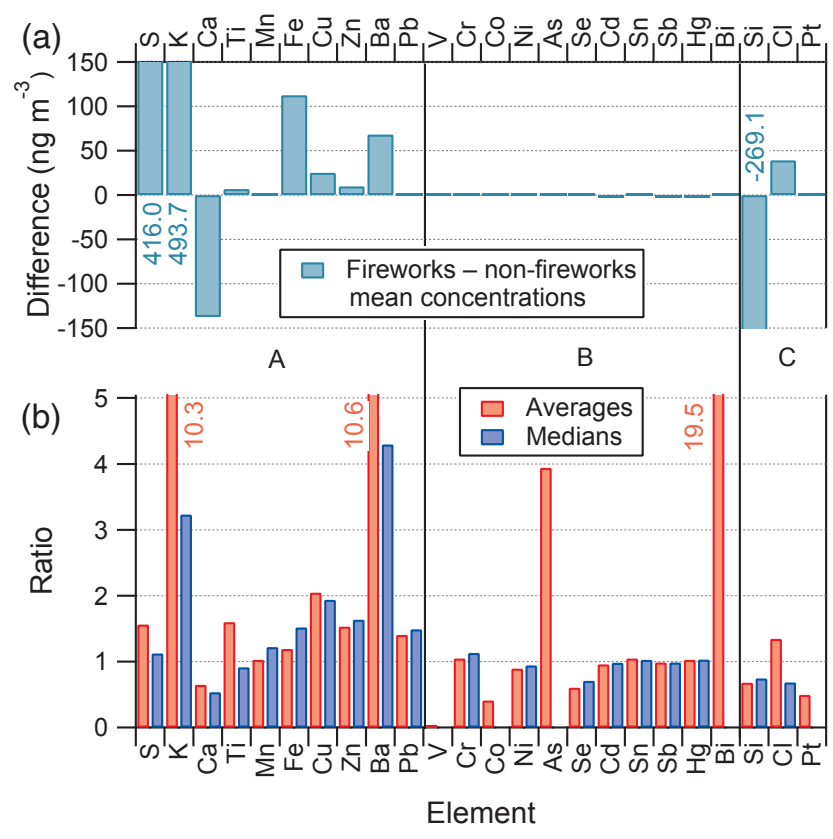

Figure 7. (a) Difference between average concentrations of fireworks and non-fireworks periods. Numbers indicate values outside the axis range for $\mathrm{S}, \mathrm{K}$, and $\mathrm{Si}$ (negative). (b) Enhancement ratios for all analysed elements for fireworks/non-fireworks classification, sorted by group. Numbers indicate values outside the axis range for $\mathrm{S}, \mathrm{K}$, and $\mathrm{Si}$.

fireworks cases the transition elements $\mathrm{Mn}, \mathrm{Fe}, \mathrm{Zn}$, and the element $\mathrm{Pb}$ are characterized by a broad morning peak with a maximum around 10:00 LT, correlating well with the increasing traffic in the morning hours and the breakup of the temperature inversion.

To identify the fireworks tracers, an enhancement ratio (ER) was defined as the ratio between the mean concentrations of an element for the fireworks period to the concentrations in the non-fireworks period (Fig. 7). For $\mathrm{K}, \mathrm{Cu}$, and $\mathrm{Ba}$ the ER is larger than $2(\mathrm{Cu})$ and goes up to $10.6(\mathrm{Ba}) . \mathrm{S}$, $\mathrm{Cl}, \mathrm{Ti}, \mathrm{Zn}$, and $\mathrm{Pb}$ show an intermediate ER between 1 and 2. $\mathrm{Cr}, \mathrm{Mn}$, and Fe ER are close to 1 . Si and $\mathrm{Ca}$ are depleted with an ER around 0.5, both of which are probably related to the above weekend effect. The elements with the high ER are clearly identified as elements of fireworks: $\mathrm{S}, \mathrm{K}, \mathrm{Ti}, \mathrm{Cu}, \mathrm{Zn}$, $\mathrm{Ba}$, and $\mathrm{Bi}$.

Further refinement of sources can be obtained when classifying the non-fireworks data by wind direction into a north $\left(270-0-90^{\circ}\right)$ and a south $\left(90-180-270^{\circ}\right)$ sector (Fig. 8), with the south sector more strongly influenced by highway emissions (Hueglin et al., 2006). The north sector characterizes the (rural) background concentrations of the central Swiss plateau. Table S1 summarizes the mean element concentrations for the campaign divided into the different periods and wind sectors. $\mathrm{Ba}, \mathrm{Cr}, \mathrm{Cu}, \mathrm{Fe}$, and $\mathrm{Mn}$ show the signature of continuous freeway traffic emissions during the day. $\mathrm{Pb}$ and $\mathrm{Zn}$ show a morning peak only and are well correlated in both 

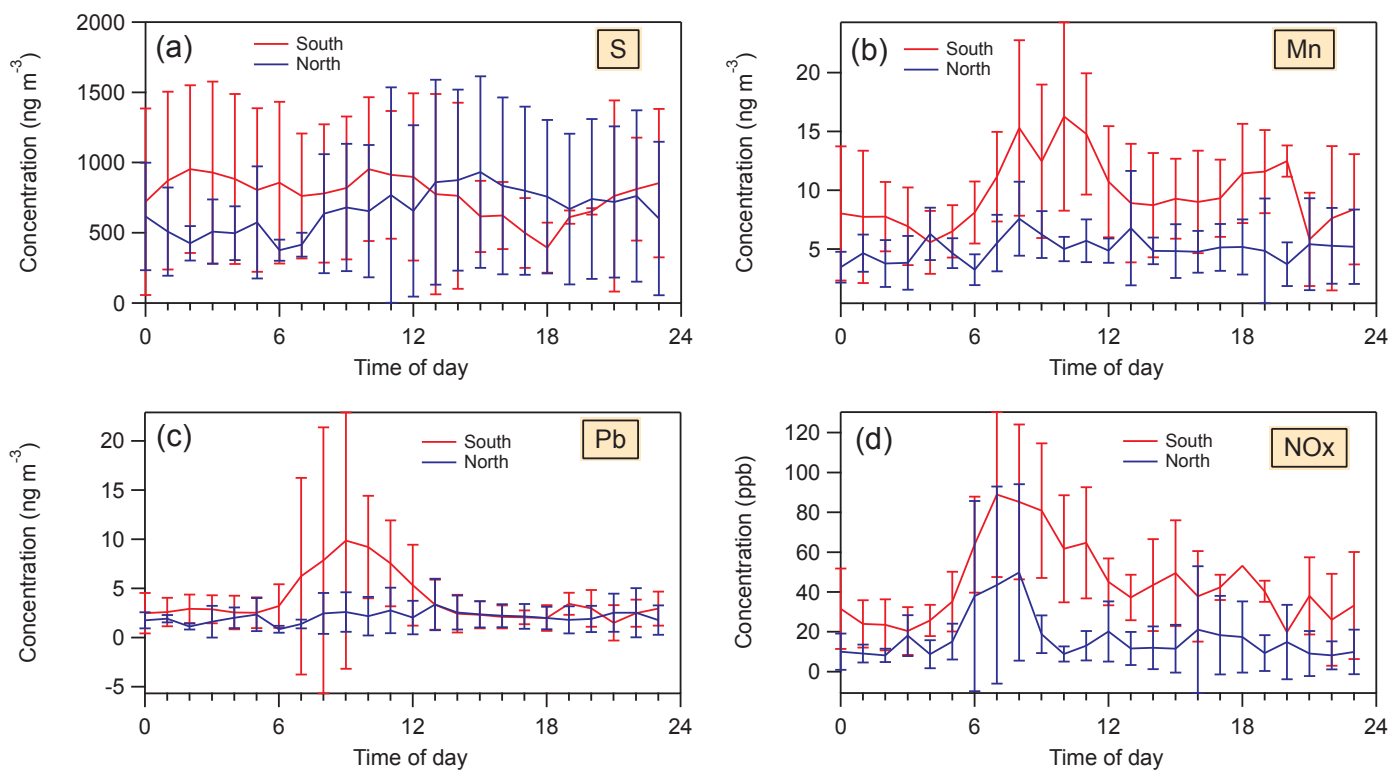

Figure 8. Mean diurnal variations of (a) $\mathrm{S}$, (b) $\mathrm{Mn}$, (c) $\mathrm{Pb}$, and (d) $\mathrm{NO}_{x}$ for the non-fireworks period stratified for south and north wind directions. Error bars denote \pm 1 standard deviation of the averaging period. Diurnal variations for the other elements are shown in Fig. S5.

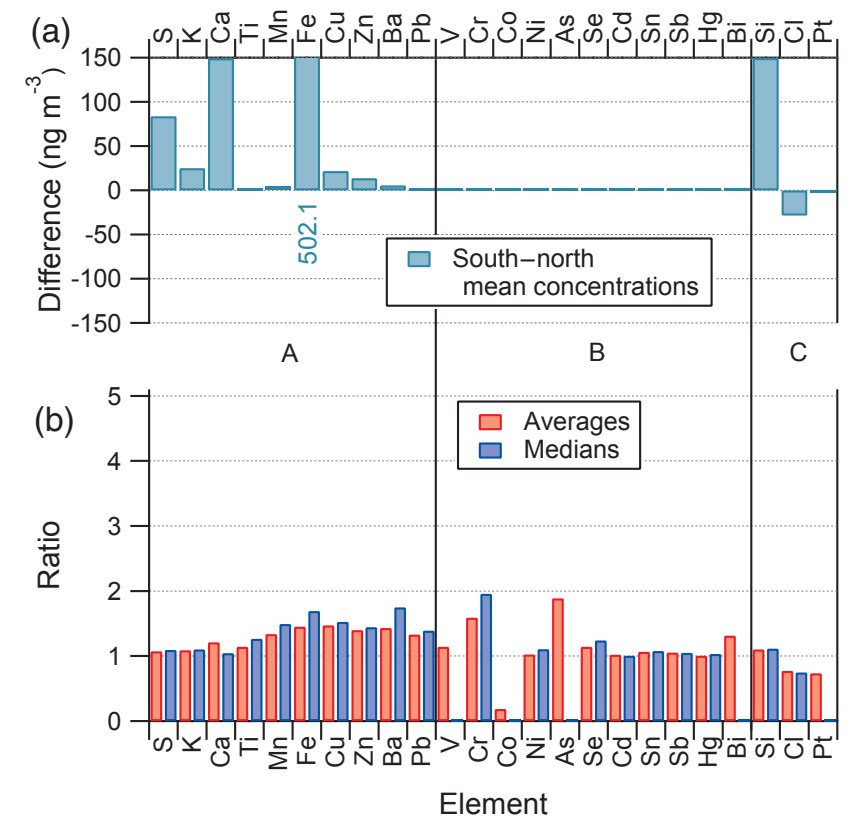

Figure 9. (a) "Background"-subtracted mean concentrations of the south sector for the non-fireworks period. Number indicates value outside the axis range for Fe. (b) Enhancement ratios for all analysed elements for south-north sector classification for the nonfireworks period, sorted by group.

sectors. $\mathrm{Si}, \mathrm{K}, \mathrm{Ca}$, and $\mathrm{Ti}$ show another pattern that could reflect the local and regional transport of crustal material partly re-suspended by traffic (south sector), partly originating from the agricultural area north of the freeway.
Figure 9 shows the enhancement ratios south-north. Apart from $\mathrm{Cl}$, all south-north differences are positive, and $\mathrm{Si}$, $\mathrm{S}, \mathrm{Ca}$, and $\mathrm{Fe}$ concentration differences are larger than $80 \mathrm{ng} \mathrm{m}^{-3}$. These are mainly crustal elements (although $\mathrm{Fe}$ is also emitted from vehicles). The enhancement ratios of the transition elements $\mathrm{Cr}, \mathrm{Mn}, \mathrm{Fe}, \mathrm{Cu}, \mathrm{Zn}, \mathrm{Ba}$, and $\mathrm{Pb}$ are larger than 1.2 and related to traffic emissions (engine abrasion, tyre wear, brake wear).

\section{Conclusions}

A 3-week test of a Cooper Environmental Xact 625 Ambient Metals Monitor was performed at the Swiss NABEL station Härkingen. The instrument was configured to measure 24 elements continuously with $1 \mathrm{~h}$ time resolution. The selection of elements ranged from $\mathrm{Si}$ to $\mathrm{Bi}$, thus covering a range of environmentally relevant elements. Besides the "standard" elements from $\mathrm{K}$ to $\mathrm{Pb}$, which have been well characterized by the manufacturer with respect to their accuracies and detection limits, we included several abundant light elements $(\mathrm{Si}, \mathrm{S}, \mathrm{Cl})$ and - more for curiosity - some low-concentration elements (As, Pt, $\mathrm{Hg}$ ) in our selection to test the behaviour of the instrument in a typical Swiss environment. We tested the measurement quality of the Xact 625 by intercomparison with well-established methodologies (ICP-OES and ICP-MS analyses on $24 \mathrm{~h} \mathrm{PM} 10$ samples for major and trace elements and AuAAA for $\mathrm{Hg}$ ), ACSM, and TEOM and used additional meteorological data for the interpretation of the results.

The general findings are as follows:

- The total of elements analysed with the Xact comprised approximately $20 \%$ of the $\mathrm{PM}_{10}$ mass. 
- The Xact 625 produced element concentration time series that were highly correlated with the ICP analyses of $24 \mathrm{~h}$ filter samples $\left(r^{2} \geq 0.95\right)$, even though the slopes deviated from 1.

- Element concentrations ranged from $\mathrm{ng} \mathrm{m}^{-3}$ (in background conditions) to tens of $\mu \mathrm{g} \mathrm{m}^{-3}$ (during the fireworks), and no instability in operation due to sample overload or else could be observed.

- The measured concentrations agreed reasonably well with other recent field measurements in Switzerland.

The results for measurement accuracy, precision, and data quality are as follows:

- Excellent correlation between Xact 625 and ICPOES/ICP-MS was observed for $24 \mathrm{~h}$ averages of the elements $\mathrm{S}, \mathrm{K}, \mathrm{Ca}, \mathrm{Ti}, \mathrm{Mn}, \mathrm{Fe}, \mathrm{Cu}, \mathrm{Zn}, \mathrm{Ba}$, and $\mathrm{Pb}$ (Group A). The daily averages calculated from hourly measurements by Xact were on average $30 \%$ higher (range -3 to $+80 \%$, depending on the element) than $24 \mathrm{~h}$ integrated filter measurements by ICP. Systematic differences of on average 25 to $30 \%$ could be attributed to physical reasons in the experiment settings, such as the different characteristics of the two inlet systems, the distance between the inlets and to the main source (freeway), and uncertainties in the various analysis methods. For XRF this includes particle-size-dependent selfabsorption effects for the lighter elements and line interferences between different elements. For ICP this includes the entire sampling, digestion, and the analysis procedure, as indicated by limited inter-laboratory and inter-method comparisons, as well as the impurities in blank filters. Further research on these issues is needed.

- The accuracy of hourly values has only been tested for the case of the fireworks peak late on 1 August 2015, where the sum of all elements has been compared to the total mass of the NABEL TEOM. Good agreement between the Xact and TEOM mass was found when corrections derived from the $24 \mathrm{~h}$ filter analyses were applied. This was a special case dominated by just three elements, $\mathrm{S}, \mathrm{K}$, and $\mathrm{Cl}$, and a generalization of all measured elements is not recommended.

- The remaining elements (Group B) of the filter intercomparison, $\mathrm{V}, \mathrm{Cr}, \mathrm{Co}, \mathrm{Ni}, \mathrm{As}, \mathrm{Se}, \mathrm{Cd}, \mathrm{Sn}, \mathrm{Sb}, \mathrm{Hg}$, and $\mathrm{Bi}$ (11 elements), were mostly below detection limit of at least one method or showed issues with the analysis procedures ( $\mathrm{Sn}, \mathrm{Sb}, \mathrm{Hg}$ ). A general quantitative statement on their quality could not be achieved. Notice here that a longer sampling time, e.g. 2 or $4 \mathrm{~h}$, would have lowered the Xact MDLs and therefore increased the number of good measurements, but at the cost of a reduced time resolution.
- $\mathrm{Si}$ and $\mathrm{Cl}$ were not analysed on the filters, and their Xact detection limits have not yet been determined. Hence their accuracies could not be quantified directly. Some indirect approaches were calculated.

- The Pt concentrations reported by the Xact 625 were below MDL, and Pt was not analysed on the filters. No conclusion about the accuracy of this difficult to measure element can be drawn.

Compared to rotating drum impactor sampling with synchrotron radiation induced XRF or streaker sampling with PIXE analysis, the Xact 625 measures ambient concentrations of the most relevant elements in near real time and provides data with a delay of only one sampling/analysis cycle. The continuous operation capability of Xact also circumvents the sample number limitations due to restricted beamtime assignments at synchrotrons. This is a major advantage compared to the usual time delay of a couple months caused by the restricted access to synchrotron or accelerator facilities. Of course, the high time resolution of the Xact 625 comes at the cost of sensitivity, visible in the MDLs, which are higher than the MDLs for the offline methods. Xact can be set for longer sampling intervals to extend the number of samples with analysed elements above their MDLs depending on the objective of monitoring campaigns. Xact streamlines near-real-time monitoring of multi-metals despite not being as cost effective relative to conventional samplers that could be deployed in larger numbers at many sites simultaneously or that could sample several size fractions at once, although their actual analysis costs (laboratories, accelerator facilities and staffing needs) are not considered here and they may surmount the instrument costs manifold. Overall, hightime-resolution sampling of metals provides a rich dataset for associating high-metal-concentration episodes with source emission activities. Useful extensions of the present capabilities of the Xact could be the addition of more elements to be analysed (especially under the circumstance that the full mix of observed elements cannot always be known in advance), improved quantification of the lightest elements (especially their MDLs), a vacuum or helium device for analysing light elements like $\mathrm{Na}$ and $\mathrm{Mg}$, and an inlet switch to alternately measure $\mathrm{PM}_{10}$ and $\mathrm{PM}_{2.5}$ with one single instrument.

Data availability. The datasets are available upon request to the corresponding author.

\section{The Supplement related to this article is available online at https://doi.org/10.5194/amt-10-2061-2017-supplement.}

Competing interests. Krag Petterson and Varun Yadav are employed by Cooper Environmental Services, the manufacturer of the $\mathrm{Xact}^{\circledR} 625$. 
Acknowledgements. This study has been partly funded by the Swiss Federal Office for the Environment (FOEN). M. C. Minguillón acknowledges the Ramón y Cajal Fellowship awarded by the Spanish Ministry of Economy, Industry and Competitiveness. We thank René Richter and Roland Scheidegger of PSI for their support during the field campaign. We are grateful to Chris Koch and John Cooper of Cooper Environmental Services for instructions on instrument operation and numerous discussions on the results. Andrés Alastuey, Xavier Querol, and laboratory personnel from IDAEA-CSIC are also acknowledged. We also thank Julie Swift and Randy Mercurio of ERG for the ICP-MS analyses.

Edited by: W. Maenhaut

Reviewed by: three anonymous referees

\section{References}

ACES: Equivalence of $\mathrm{PM}_{10}$ instruments at a road traffic site, Stockholm University, Stockholm, Sweden, 67 pp., 2012.

Alastuey, A., Querol, X., Aas, W., Lucarelli, F., Pérez, N., Moreno, T., Cavalli, F., Areskoug, H., Balan, V., Catrambone, M., Ceburnis, D., Cerro, J. C., Conil, S., Gevorgyan, L., Hueglin, C., Imre, K., Jaffrezo, J.-L., Leeson, S. R., Mihalopoulos, N., Mitosinkova, M., O’Dowd, C. D., Pey, J., Putaud, J.-P., Riffault, V., Ripoll, A., Sciare, J., Sellegri, K., Spindler, G., and Yttri, K. E.: Geochemistry of $\mathrm{PM}_{10}$ over Europe during the EMEP intensive measurement periods in summer 2012 and winter 2013, Atmos. Chem. Phys., 16, 6107-6129, https://doi.org/10.5194/acp16-6107-2016, 2016.

Annegarn, H. J., Braga Marcazzan, G. M., Cereda, E., Marchionni, M., and Zucchiatti, A.: Source profiles by unique ratios (SPUR) analysis: Determination of source profiles from receptor-site streaker samples, Atmos. Environ. A-Ge., 26, 333-343, 1992.

BAFU and Empa: NABEL - Luftbelastung 2014, Bern, Switzerland, UZ-1515-D, 132 pp., 2015.

Botasini, S., Heijo, G., and Méndez, E.: Toward decentralized analysis of mercury (II) in real samples. A critical review on nanotechnology-based methodologies, Anal. Chim. Acta, 800, 1-11, 2013.

Bukowiecki, N., Hill, M., Gehrig, R., Zwicky, C. N., Lienemann, P., Hegedüs, F., Falkenberg, G., Weingartner, E., and Baltensperger, U.: Trace metals in ambient air: Hourly size-segregated mass concentrations determined by synchrotron-XRF, Environ. Sci. Technol., 39, 5754-5762, 2005.

Bukowiecki, N., Lienemann, P., Zwicky, C. N., Furger, M., Richard, A., Falkenberg, G., Rickers, K., Grolimund, D., Borca, C., Hill, M., Gehrig, R., and Baltensperger, U.: X-ray fluorescence spectrometry for high throughput analysis of atmospheric aerosol samples: The benefits of synchrotron X-rays, Spectrochim. Acta B, 63, 929-938, 2008.

Bukowiecki, N., Lienemann, P., Hill, M., Figi, R., Richard, A., Furger, M., Rickers, K., Falkenberg, G., Zhao, Y., Cliff, S. S., Prevot, A. S. H., Baltensperger, U., Buchmann, B., and Gehrig, R.: Real-world emission factors for antimony and other brake wear related trace elements: Size-segregated values for light and heavy duty vehicles, Environ. Sci. Technol., 43, 8072-8078, 2009.
Bukowiecki, N., Lienemann, P., Hill, M., Furger, M., Richard, A., Amato, F., Prévôt, A. S. H., Baltensperger, U., Buchmann, B., and Gehrig, R.: $\mathrm{PM}_{10}$ emission factors for non-exhaust particles generated by road traffic in an urban street canyon and along a freeway in Switzerland, Atmos. Environ., 44, 2330-2340, 2010.

Calzolai, G., Chiari, M., Lucarelli, F., Nava, S., and Portarena, S.: Proton induced $\gamma$-ray emission yields for the analysis of light elements in aerosol samples in an external beam set-up, Nucl. Instrum. Meth. Phys. B, 268, 1540-1545, 2010.

Calzolai, G., Lucarelli, F., Chiari, M., Nava, S., Giannoni, M., Carraresi, L., Prati, P., and Vecchi, R.: Improvements in PIXE analysis of hourly particulate matter samples, Nucl. Instrum. Meth. Phys. B, 363, 99-104, 2015.

Chiaradia, M. and Cupelin, F.: Gas-to-particle conversion of mercury, arsenic and selenium through reactions with traffic-related compounds? Indications from lead isotopes, Atmos. Environ., 34, 327-332, 2000.

Crenn, V., Sciare, J., Croteau, P. L., Verlhac, S., Fröhlich, R., Belis, C. A., Aas, W., Äijälä, M., Alastuey, A., Artiñano, B., Baisnée, D., Bonnaire, N., Bressi, M., Canagaratna, M., Canonaco, F., Carbone, C., Cavalli, F., Coz, E., Cubison, M. J., Esser-Gietl, J. K., Green, D. C., Gros, V., Heikkinen, L., Herrmann, H., Lunder, C., Minguillón, M. C., Mocnik, G., O’Dowd, C. D., Ovadnevaite, J., Petit, J.-E., Petralia, E., Poulain, L., Priestman, M., Riffault, V., Ripoll, A., Sarda-Estève, R., Slowik, J. G., Setyan, A., Wiedensohler, A., Baltensperger, U., Prévôt, A. S. H., Jayne, J. T., and Favez, O.: ACTRIS ACSM intercomparison - Part 1: Reproducibility of concentration and fragment results from 13 individual Quadrupole Aerosol Chemical Speciation Monitors (Q-ACSM) and consistency with co-located instruments, Atmos. Meas. Tech., 8, 5063-5087, https://doi.org/10.5194/amt-8-50632015, 2015.

Currie, L.: Detection and quantification in X-ray fluorescence spectrometry. In: X-Ray fluorescence analysis of environmental samples, edited by: Dzubay, T. G., IX, Ann Arbor Science Publishers, 289-306, 1977.

D’Alessandro, A., Lucarelli, F., Mandò, P. A., Marcazzan, G., Nava, S., Prati, P., Valli, G., Vecchi, R., and Zucchiatti, A.: Hourly elemental composition and sources identification of fine and coarse $\mathrm{PM}_{10}$ particulate matter in four Italian towns, J. Aerosol. Sci., 34, 243-259, 2003.

Diez, S., Montuori, P., Querol, X., and Bayona, J. M.: Total mercury in the hair of children by combustion atomic absorption spectrometry (Comb-AAS), J. Anal. Toxicol., 31, 144-149, 2007.

Drewnick, F., Hings, S. S., Curtius, J., Eerdekens, G., and Williams, $\mathrm{J}$.: Measurement of fine particulate and gas-phase species during the New Year's fireworks 2005 in Mainz, Germany, Atmos. Environ., 40, 4316-4327, 2006.

Escrig, A., Monfort, E., Celades, I., Querol, X., Amato, F., Minguillón, M. C., and Hopke, P. K.: Application of optimally scaled target factor analysis for assessing source contribution of ambient $\mathrm{PM}_{10}$, J. Air Waste Manage., 59, 1296-1307, 2009.

Formenti, P., Nava, S., Prati, P., Chevaillier, S., Klaver, A., Lafon, S., Mazzei, F., Calzolai, G., and Chiari, M.: Selfattenuation artifacts and correction factors of light element measurements by X-ray analysis: Implication for mineral dust composition studies, J. Geophys. Res.-Atmos., 115, D01203, https://doi.org/10.1029/2009JD012701, 2010. 
Gälli Purghart, B. C., Nyffeler, U. P., Schindler, P. W., Van Borm, W. A., and Adams, F. C.: Metals in airborne particulate matter in rural Switzerland, Atmos. Environ. A.-Gen., 24, 2191-2206, 1990.

Gerboles, M., Buzica, D., Brown, R. J. C., Yardley, R. E., HanusIllnar, A., Salfinger, M., Vallant, B., Adriaenssens, E., Claeys, N., Roekens, E., Sega, K., Jurasovic, J., Rychlik, S., Rabinak, E., Tanet, G., Passarella, R., Pedroni, V., Karlsson, V., Alleman, L., Pfeffer, U., Gladtke, D., Olschewski, A., O'Leary, B., O'Dwyer, M., Pockeviciute, D., Biel-Cwikowska, J., and Tursic, J.: Interlaboratory comparison exercise for the determination of As, Cd, $\mathrm{Ni}$ and $\mathrm{Pb}$ in $\mathrm{PM}_{10}$ in Europe, Atmos. Environ., 45, 3488-3499, 2011.

Gianini, M. F. D., Gehrig, R., Fischer, A., Ulrich, A., Wichser, A., and Hueglin, C.: Chemical composition of $\mathrm{PM}_{10}$ in Switzerland: An analysis for 2008/2009 and changes since 1998/1999, Atmos. Environ., 54, 97-106, 2012.

Hagler, G. S. W., Baldauf, R. W., Thoma, E. D., Long, T. R., Snow, R. F., Kinsey, J. S., Oudejans, L., and Gullett, B. K.: Ultrafine particles near a major roadway in Raleigh, North Carolina: Downwind attenuation and correlation with traffic-related pollutants, Atmos. Environ., 43, 1229-1234, 2009.

Hopke, P. K.: Review of receptor modeling methods for source apportionment, J. Air Waste Manage., 66, 237-259, 2016.

Hueglin, C., Gehrig, R., Baltensperger, U., Gysel, M., Monn, C., and Vonmont, H.: Chemical characterisation of $\mathrm{PM}_{2.5}, \mathrm{PM}_{10}$ and coarse particles at urban, near-city and rural sites in Switzerland, Atmos. Environ., 39, 637-651, 2005.

Hueglin, C., Buchmann, B., and Weber, R. O.: Long-term observation of real-world road traffic emission factors on a motorway in Switzerland, Atmos. Environ., 40, 3696-3709, 2006.

Kong, S. F., Li, L., Li, X. X., Yin, Y., Chen, K., Liu, D. T., Yuan, L., Zhang, Y. J., Shan, Y. P., and Ji, Y. Q.: The impacts of firework burning at the Chinese Spring Festival on air quality: insights of tracers, source evolution and aging processes, Atmos. Chem. Phys., 15, 2167-2184, https://doi.org/10.5194/acp15-2167-2015, 2015.

Lanz, V. A., Prévôt, A. S. H., Alfarra, M. R., Weimer, S., Mohr, C., DeCarlo, P. F., Gianini, M. F. D., Hueglin, C., Schneider, J., Favez, O., D'Anna, B., George, C., and Baltensperger, U.: Characterization of aerosol chemical composition with aerosol mass spectrometry in Central Europe: an overview, Atmos. Chem. Phys., 10, 10453-10471, https://doi.org/10.5194/acp-10-104532010, 2010.

Lucarelli, F., Nava, S., Calzolai, G., Chiari, M., Udisti, R., and Marino, F.: Is PIXE still a useful technique for the analysis of atmospheric aerosols? The LABEC experience, X-Ray Spectrom., 40, 162-167, 2011.

Lundgren, D. A.: An aerosol sampler for determination of particle concentration as a function of size and time, J. Air Waste Manage., 17, 225-229, 1967.

Middlebrook, A. M., Bahreini, R., Jimenez, J. L., and Canagaratna, M. R.: Evaluation of composition-dependent collection efficiencies for the Aerodyne aerosol mass spectrometer using field data, Aerosol Sci. Tech., 46, 258-271, 2012.

Minguillón, M. C., Querol, X., Baltensperger, U., and Prévôt, A. S. H.: Fine and coarse PM composition and sources in rural and urban sites in Switzerland: Local or regional pollution?, Sci. Total Environ., 427-428, 191-202, 2012.
Moreno, T., Querol, X., Alastuey, A., Minguillón, M. C., Pey, J., Rodriguez, S., Miró, J. V., Felis, C., and Gibbons, W.: Recreational atmospheric pollution episodes: Inhalable metalliferous particles from firework displays, Atmos. Environ., 41, 913-922, 2007.

Ng, N. L., Herndon, S. C., Trimborn, A., Canagaratna, M. R., Croteau, P. L., Onasch, T. B., Sueper, D., Worsnop, D. R., Zhang, Q., Sun, Y. L., and Jayne, J. T.: An aerosol chemical speciation monitor (ACSM) for routine monitoring of the composition and mass concentrations of ambient aerosol, Aerosol Sci. Tech., 45, 780-794, 2011.

Panteliadis, P., Helmink, H. J. P., Koopman, P. C., Hoonhout, M., de Jonge, D., and Visser, J. H.: PM $_{10}$ sampling inlets comparison: EPA vs EU, European Aerosol Conference, Granada, Spain, 2012.

Park, S.-S., Cho, S. Y., Jo, M. R., Gong, B. J., Park, J. S., and Lee, S. J.: Field evaluation of a near-real time elemental monitor and identification of element sources observed at an air monitoring supersite in Korea, Atmos. Pollut. Res., 5, 119-128, 2014.

Querol, X., Alastuey, A., Rodriguez, S., Plana, F., Ruiz, C. R., Cots, N., Massagué, G., and Puig, O.: $\mathrm{PM}_{10}$ and $\mathrm{PM}_{2.5}$ source apportionment in the Barcelona metropolitan area, Catalonia, Spain, Atmos. Environ., 35, 6407-6419, 2001.

Querol, X., Viana, M., Alastuey, A., Amato, F., Moreno, T., Castillo, S., Pey, J., de la Rosa, J., Sánchez de la Campa, A., Artíñano, B., Salvador, P., García Dos Santos, S., Fernández-Patier, R., Moreno-Grau, S., Negral, L., Minguillón, M. C., Monfort, E., Gil, J. I., Inza, A., Ortega, L. A., Santamaría, J. M., and Zabalza, J.: Source origin of trace elements in PM from regional background, urban and industrial sites of Spain, Atmos. Environ., 41, 7219-7231, 2007.

Querol, X., Pey, J., Minguillón, M. C., Pérez, N., Alastuey, A., Viana, M., Moreno, T., Bernabé, R. M., Blanco, S., Cárdenas, B., Vega, E., Sosa, G., Escalona, S., Ruiz, H., and Artíñano, B.: PM speciation and sources in Mexico during the MILAGRO-2006 Campaign, Atmos. Chem. Phys., 8, 111-128, https://doi.org/10.5194/acp-8-111-2008, 2008.

Richard, A., Bukowiecki, N., Lienemann, P., Furger, M., Fierz, M., Minguillón, M. C., Weideli, B., Figi, R., Flechsig, U., Appel, K., Prévôt, A. S. H., and Baltensperger, U.: Quantitative sampling and analysis of trace elements in atmospheric aerosols: impactor characterization and Synchrotron-XRF mass calibration, Atmos. Meas. Tech., 3, 1473-1485, https://doi.org/10.5194/amt-3-14732010, 2010.

Richard, A., Gianini, M. F. D., Mohr, C., Furger, M., Bukowiecki, N., Minguillón, M. C., Lienemann, P., Flechsig, U., Appel, K., DeCarlo, P. F., Heringa, M. F., Chirico, R., Baltensperger, U., and Prévôt, A. S. H.: Source apportionment of size and time resolved trace elements and organic aerosols from an urban courtyard site in Switzerland, Atmos. Chem. Phys., 11, 8945-8963, https://doi.org/10.5194/acp-11-8945-2011, 2011.

Röösli, M., Theis, G., Künzli, N., Staehelin, J., Mathys, P., Oglesby, L., Camenzind, M., and Braun-Fahrländer, C.: Temporal and spatial variation of the chemical composition of $\mathrm{PM}_{10}$ at urban and rural sites in the Basel area, Switzerland, Atmos. Environ., 35, 3701-3713, 2001.

Sánchez-Rodas, D., Sánchez de la Campa, A. M., de la Rosa, J. D., Oliveira, V., Gómez-Ariza, J. L., Querol, X., and Alastuey, A.: Arsenic speciation of atmospheric particulate matter $\left(\mathrm{PM}_{10}\right)$ in 
an industrialised urban site in southwestern Spain, Chemosphere, 66, 1485-1493, 2007.

Sarmiento, A. M., Oliveira, V., Gómez-Ariza, J. L., Nieto, J. M., and Sánchez-Rodas, D.: Diel cycles of arsenic speciation due to photooxidation in acid mine drainage from the Iberian Pyrite Belt (Sw Spain), Chemosphere, 66, 677-683, 2007.

Visser, S., Slowik, J. G., Furger, M., Zotter, P., Bukowiecki, N., Canonaco, F., Flechsig, U., Appel, K., Green, D. C., Tremper, A. H., Young, D. E., Williams, P. I., Allan, J. D., Coe, H., Williams, L. R., Mohr, C., Xu, L., Ng, N. L., Nemitz, E., Barlow, J. F., Halios, C. H., Fleming, Z. L., Baltensperger, U., and Prévôt, A. S. H.: Advanced source apportionment of size-resolved trace elements at multiple sites in London during winter, Atmos. Chem. Phys., 15, 11291-11309, https://doi.org/10.5194/acp-15-112912015, 2015a.

Visser, S., Slowik, J. G., Furger, M., Zotter, P., Bukowiecki, N., Dressler, R., Flechsig, U., Appel, K., Green, D. C., Tremper, A. H., Young, D. E., Williams, P. I., Allan, J. D., Herndon, S. C., Williams, L. R., Mohr, C., Xu, L., Ng, N. L., Detournay, A., Barlow, J. F., Halios, C. H., Fleming, Z. L., Baltensperger, U., and Prévôt, A. S. H.: Kerb and urban increment of highly time-resolved trace elements in $\mathrm{PM}_{10}, \mathrm{PM}_{2.5}$ and $\mathrm{PM}_{1.0}$ winter aerosol in London during ClearfLo 2012, Atmos. Chem. Phys., 15, 2367-2386, https://doi.org/10.5194/acp15-2367-2015, $2015 b$.
Yadav, V. and Turner, J.: Gauging intraurban variability of ambient particulate matter arsenic and other air toxic metals from a network of monitoring sites, Atmos. Environ., 89, 318-328, 2014.

Yatkin, S., Gerboles, M., and Borowiak, A.: Evaluation of standardless EDXRF analysis for the determination of elements on $\mathrm{PM}_{10}$ loaded filters, Atmos. Environ., 54, 568-582, 2012.

Yatkin, S., Belis, C. A., Gerboles, M., Calzolai, G., Lucarelli, F., Cavalli, F., and Trzepla, K.: An interlaboratory comparison study on the measurement of elements in $\mathrm{PM}_{10}$, Atmos. Environ., 125, 61-68, 2016. 